\title{
Ensuring sustainability in plastics use in Africa: consumption, waste generation, and projections
}

Joshua O. Babayemi ${ }^{1,2^{*}} \mathbb{D}$, Innocent C. Nnorom ${ }^{3,4}$, Oladele Osibanjo ${ }^{5}$ and Roland Weber ${ }^{6}$

\begin{abstract}
Background: Currently, plastic is at the top of the international agenda for waste management. Recent meetings of the Conferences of the Parties to the Basel and the Stockholm Conventions have expressed concerns over the impact of plastic waste, marine plastic litter, and microplastics, and emphasised the importance of reducing consumption and ensuring the environmentally sound management of waste plastics. This study presents the first continental historical analysis of mass importation and consumption of different polymers and plastics (primary and secondary forms, respectively) in Africa and the associated pollution potential. We identified, collated and synthesised dispersed international trade data on the importation of polymers and plastics into several African countries.

Results: The 33 African countries (total population of 856,671,366) with available data for more than 10 years imported approximately $86.14 \mathrm{Mt}$ of polymers in primary form and $31.5 \mathrm{Mt}$ of plastic products between 1990 and 2017. Extrapolating to the continental level (African population of 1.216 billion in 54 countries), about $172 \mathrm{Mt}$ of polymers and plastics valued at $\$ 285$ billion were imported between 1990 and 2017. Considering also the components of products, an estimated $230 \mathrm{Mt}$ of plastics entered Africa during that time period, with the largest share going to Egypt (43 Mt, 18.7\%), Nigeria (39 Mt, 17.0\%), South Africa (27 Mt, 11.7\%), Algeria (26 Mt, 11.3\%), Morocco (22 Mt, 9.6\%), and Tunisia (16 Mt, 7.0\%). Additionally, primary plastic production in 8 African countries contributed $15 \mathrm{Mt}$ during 20092015. The assessment showed that environmentally sound end-of-life management of waste plastics by recycling and energy recovery is in its infancy in Africa, but recycling activities and thermal recovery have started in a few countries.

Conclusions: Globally, the perception is that production and consumption of plastics can only increase in the future. Solutions are needed to tackle this global challenge. Certain policies and plastic bag bans could help reduce plastic consumption in the near future, as demonstrated by Rwanda. Furthermore, there is a need for innovative solutions such as the introduction of biodegradable polymers and other alternatives, especially for packaging.
\end{abstract}

Keywords: Plastics, Consumption, Waste management, Africa, United Nations Comtrade

\footnotetext{
*Correspondence: babayemola@gmail.com

2 Department of Chemical Sciences, Anchor University, Lagos, Nigeria

Full list of author information is available at the end of the article
} 


\section{Background}

In recent decades, the production and consumption of plastics have increased owing to increasing applications that rely on the good characteristics of plastics such as light weight, strength, durability, affordability, corrosion resistance and low production costs [1]. Between 1950 and 2015, about 8300 million tonnes (Mt) of virgin plastics were produced across the globe, generating approximately $6300 \mathrm{Mt}$ of plastic wastes, of which around 9\% have been recycled, $12 \%$ incinerated, and $79 \%$ accumulated in landfills [2]. Current worldwide production of plastics is around $300 \mathrm{Mt} /$ year, with $57 \mathrm{Mt} /$ year produced in the European Union [3]. Globally, the yearly average per capita plastic consumption is $43 \mathrm{~kg}$ [4]. In India, the consumption of plastics increased from $0.4 \mathrm{Mt} /$ year in 1990 to $4 \mathrm{Mt} /$ year in 2001, and it was expected to rise to $8 \mathrm{Mt} /$ year in 2009 [5] and $16.5 \mathrm{Mt} /$ year in 2017/18 [6]. In Asia, plastic use is $20 \mathrm{~kg} / \mathrm{capita} /$ year, while in Western Europe and North America the average is $100 \mathrm{~kg} / \mathrm{capita} /$ year [7]. Plastic consumption increases with GDP [8]. ${ }^{1}$ Waste plastic represents a considerable proportion of the total waste stream in many countries. The total mismanaged plastic waste globally in 2010 was estimated at 32 Mt [9]. Currently, plastic waste poses human and environmental issues globally and especially for African countries, which have a high proportion of mismanaged waste plastics and lack state-of-the-art recycling facilities [10].

Depending on type and use, plastic contains a wide range of additives such as plasticizers, flame retardants, antioxidants, acid scavengers, light and heat stabilisers, lubricants, pigments, antistatic agents, slip compounds, and thermal stabilizers. These additives are used in plastics for various purposes [2, 11-14]. Many of these additives have toxic effects and some are classified as endocrine disrupting chemicals [EDCs; e.g. bisphenol A or diethylhexylphthalate (DEHP)]. Several others have been listed as persistent organic pollutants (POPs), including the flame retardants polybrominated diphenyl ethers (PBDEs), hexabromobiphenyls (HBB), hexabromocyclododecane (HBCD), short-chain chlorinated paraffins (SCCPs) and the fluorinated tensides like perfluorooctanoic acid (PFOA). The largest share of plastics however is not flame retarded and does not contain POPs as additives.

Inappropriate use and disposal of waste plastics may result in the release of toxic substances, which is facilitated by open burning of e-waste plastics from vehicles and cables [15-18]. Hazardous chemicals can also

\footnotetext{
${ }^{1}$ https://ourworldindata.org/grapher/per-capita-plastic-waste-vs-gdp-percapita.
}

migrate from the plastic matrix leading to exposure via direct contact, for example from toys or kitchen tools that are partly produced from recycled plastic [15] or soft PVC used in toys or medical devices $[19,20]$. On the other hand, additives in food packaging plastics or water bottles are controlled and regulated in industrialised countries. In Africa, the regulations on plastic additives and other chemicals in products are weak [21, 22].

Furthermore, most polymers are resistant to degradation, thus most plastic debris may persist in the environment for decades or centuries [22, 23] and may be transported far from the source [1]. An estimated over 4 Mt of plastic waste generated on land entered the marine environment in 2010 alone [9]. Currently this is estimated at $8 \mathrm{Mt} /$ year [4]. The most common monomers used to make plastics are derived from fossil hydrocarbons and the resulting products are not biodegradable [2], hence the high persistence in the environment.

Currently, plastic is at the top of the international agenda for waste management. Recent meetings of the Conferences of the Parties to the Basel and the Stockholm Conventions "encouraged regional and coordinating centres to work, under the Convention, on the impact of plastic waste, marine plastic litter, microplastics and measures for prevention and environmentally sound management" [14]. Mixed plastic waste was listed in the Basel Convention Annexes as hazardous waste to control during international trade [24]. The global problem of increasing plastic waste and the associated pollution, marine litter, biodiversity and human health effects were recognised at each of the first four meetings of the United Nations Environment Assembly (UNEA 4). UNEA 4 addresses the analysis of voluntary commitments targeting marine litter and microplastics pursuant to Resolution 3/7 (UNEP/ EA.3/Res.7.).

In a previous study, we compiled primary data on plastic imports into Nigeria [25]. Our study revealed that large amounts of plastics have entered Nigeria over the years, but robust continental-scale information is still lacking in Africa. Many data gaps have been identified in Africa concerning plastics and the associated wastes [10]. We present the first historical analysis of mass importation of polymers and plastics in primary and secondary forms and the associated pollution potential in Africa by identifying and synthesising dispersed international trade data on plastic importation and local production. The connection between trade and inventory data and the waste and pollution potential can eventually be used as a tool to develop counter-measures, improve prevention and management programmes, and calculate recycling quotas [25]. We also assessed the volume 
Table 1 HS classification of plastics and articles thereof

\begin{tabular}{|c|c|}
\hline HS code & Classification of plastics \\
\hline 3901 & Polymers of ethylene, in primary forms \\
\hline 3902 & Polymers of propylene or other olefins, primary forms \\
\hline 3903 & Polymers of styrene, in primary forms \\
\hline 3904 & Polymers of vinyl chloride, etc., in primary forms \\
\hline 3905 & $\begin{array}{l}\text { Polymers of vinyl acetate and other vinyl polymers, primary } \\
\text { forms }\end{array}$ \\
\hline 3906 & Acrylic polymers in primary forms \\
\hline 3907 & Polyethers, epoxides and polyesters, primary forms \\
\hline 3908 & Polyamides in primary forms \\
\hline 3909 & Amino resins, phenolics and polyurethanes, primary form \\
\hline 3910 & Silicones, in primary forms \\
\hline 3911 & Petro resins, polysulfides, etc. nesoi, primary form \\
\hline 3912 & Cellulose and chemical derivatives nesoi, primary forms \\
\hline 3913 & Natural (inc modified) polymers nesoi, primary forms \\
\hline 3914 & lon-exchangers based on plastics, in primary forms \\
\hline 3915 & Waste, parings and scrap, of plastics \\
\hline 3916 & Monofil, cr-sect ovimm, rods, sticks, etc., plastics \\
\hline 3917 & Tubes, pipes and hoses and their fittings, of plastics \\
\hline 3918 & Floor cover (rolls and tiles) and wall cover, plastics \\
\hline 3919 & Self-adhesive plates, sheets, film, etc. of plastics \\
\hline 3920 & Plates, sheets, film, etc. no ad, non-cel, etc., plast \\
\hline 3921 & Plates, sheets, film, foil and strip nesoi, plastics \\
\hline 3922 & Baths, washbasins, lavatory seats, etc. of plastics \\
\hline 3923 & Containers (boxes, bags, etc.), closurers, etc., plast \\
\hline 3924 & Tableware and other household articles, etc., plastics \\
\hline 3925 & Builders' ware of plastics, nesoi \\
\hline 3926 & Articles of plastics (including polymers and resins) nesoi \\
\hline
\end{tabular}

of wastes arising from plastic products and the recycling status in African countries.

\section{Methods}

\section{Methodology}

The method adopted followed the procedure described in Babayemi et al. [25]. It involved identifying and synthesising international trade data on the plastic imports available through the United Nations (UN) Comtrade Database $^{2}$ using harmonized system (HS) codes. The classification and HS Codes of plastics considered in this study are presented in Table 1. Estimations were also made using the information reported by Jambeck et al. $[9,10]$, such as volumes of mismanaged plastic waste and the percentage plastic waste composition of municipal solid waste. The recent literature was searched to obtain background information on polymers/plastic issues in each country under consideration. Thirty-three (33) countries with at least 10 -year records of import were considered and the results were extrapolated to the entire continent (54 countries). Available data were used to construct time trend for the six highest importing countries.

\section{Import trend}

Import trends were determined using the total amount of plastics imported in each year. Total plastics $\left(T_{y}\right)$ imported in each year was calculated using the relationship:

$$
T_{y_{1}}=\sum_{c=3901}^{3914} P_{c},
$$

for plastics imported in primary form (categories 39013914), and

$$
T_{y_{2}}=\sum_{c=3915}^{3926} P_{c},
$$

for plastics imported as product (categories 3915-3926); where $P_{c}$ is the amount of plastics in each category.

\section{Total historic consumption}

The total amount of plastics in history $\left(P_{t}\right)$ from the first $(i$ th) year to the last ( $n$ th) year was calculated as:

$$
\begin{aligned}
P_{t} & =\sum_{i=1}^{n} T_{y} \\
& =T_{y_{1}}+T_{y_{2}} .
\end{aligned}
$$

Projection

Projections were made using the forecast functions in Microsoft $\mathrm{Excel}^{3}$ [26], based on the relationship:

$$
P=a+b Y,
$$

where $P$ is the amount of plastic to be predicted for a given year, $Y$;

$$
\begin{aligned}
& a=\bar{P}-b \bar{Y} \\
& b=\frac{\sum(Y-\bar{Y})(P-\bar{P})}{\sum(Y-\bar{Y})^{2}} .
\end{aligned}
$$

The known values were the existing $Y$-values (years under study) and $P$-values (amount of plastics imported in each year), while the new value was predicted using linear regression.

\footnotetext{
${ }^{2}$ https://comtrade.un.org/.
} 
Table 2 Ranking of African countries based on the amount of plastic imports and consumption between 1990 and 2017

\begin{tabular}{|c|c|c|c|c|c|c|}
\hline Country & Population (2015) & Import period & $\begin{array}{l}\text { Plastic in primary } \\
\text { form (tonnes) } \\
T_{y_{1}}=\sum_{c=3901}^{3914} P_{c}\end{array}$ & $\begin{array}{l}\text { Plastic as plastic } \\
\text { product (tonnes) } \\
T_{y_{2}}=\sum_{c=3915}^{3926} P_{c}\end{array}$ & $\begin{array}{l}\text { Total plastics (tonnes) } \\
P_{t}=T_{y_{1}}+T_{y_{2}}\end{array}$ & $\begin{array}{l}\text { Approx. value } \\
\text { (million US\$) }^{b}\end{array}$ \\
\hline Egypt & $94,408,000$ & 1994-2017 & $17,690,897$ & $4,007,894$ & $21,698,792$ & $36,966.5$ \\
\hline Nigeria & $173,000,000$ & 1996-2017 & $15,765,771$ & $4,099,822$ & $19,865,593$ & $23,158.2$ \\
\hline South Africa & $54,956,900$ & 2000-2017 & $9,672,413$ & $4,020,752$ & $13,693,166$ & $28,299.0$ \\
\hline Algeria & $40,235,000$ & 1992-2017 & $10,499,605$ & $2,643,284$ & $13,142,889$ & $23,237.8$ \\
\hline Morocco & $33,337,529$ & 1993-2016 & $8,927,814$ & $2,348,405$ & $11,276,219$ & $21,548.1$ \\
\hline Tunisia & $10,982,754$ & 1991-2017 & $6,312,691$ & $1,752,991$ & $8,065,682$ & $17,818.1$ \\
\hline Kenya & $45,533,000$ & 1992-2017 & 3459070 & 755,371 & $4,214,440$ & 5520.9 \\
\hline Ghana & $27,043,093$ & 1996-2017 & $2,241,856$ & 967,192 & $3,209,048$ & 4286.1 \\
\hline Ethiopia & $99,391,000$ & 1995-2015 & $2,095,508$ & $1,045,286$ & $3,140,793$ & 5864.3 \\
\hline Zimbabwe & $13,061,239$ & 1995-2016 & 796,227 & $1,473,844$ & $2,270,071$ & 2118.7 \\
\hline Uganda & $34,856,813$ & 1994-2017 & $1,443,505$ & 505,236 & $1,948,741$ & 2905.9 \\
\hline Senegal & $14,354,690$ & 1996-2017 & $1,102,509$ & 497,373 & $1,599,882$ & 2506.5 \\
\hline Zambia & $15,473,905$ & 1995-2017 & 896,827 & 609,749 & $1,506,575$ & 2520.1 \\
\hline Malawi & $16,832,900$ & 1990-2015 & 510,360 & 915,778 & $1,426,137$ & 1048.9 \\
\hline Cameroon & $21,917,602$ & 1995-2017 & 852,119 & 538,971 & $1,391,089$ & 2467.0 \\
\hline Mauritius & $1,261,208$ & 1993-2017 & 605,050 & 695,342 & $1,300,392$ & 2333.5 \\
\hline Mozambique & $28,013,000$ & 1994-2017 & 664,820 & 622,595 & $1,287,414$ & 1601.1 \\
\hline Botswana & $2,024,904$ & 2000-2017 & 347,142 & 539,090 & 886,232 & 1742.8 \\
\hline Namibia & $2,280,700$ & 2000-2017 & 212,491 & 628,956 & 841,447 & 2043.2 \\
\hline Madagascar & $22,434,363$ & 1990-2017 & 434,064 & 284,433 & 718,497 & 1382.5 \\
\hline Togo & $6,191,155$ & 1994-2017 & 503,322 & 202,433 & 705,755 & 1051.2 \\
\hline Mali & $14,528,662$ & 1996-2017 & 259,211 & 237,711 & 496,922 & 783.4 \\
\hline Mauritania & $3,718,678$ & 2000-2017 & 170,134 & 307,214 & 477,348 & 423.4 \\
\hline Burkina Faso & $18,450,494$ & 1995-2016 & 124,927 & 351,621 & 476,548 & 76.6 \\
\hline Benin & $10,008,749$ & 1998-2016 & 81,018 & 305,276 & 386,293 & 368.2 \\
\hline Seychelles & 90,945 & 1994-2017 & 14,616 & 331,621 & 346,237 & 364.6 \\
\hline Guinea & $10,628,972$ & 1995-2015 & 201,223 & 127,521 & 328,744 & 295.7 \\
\hline Rwanda & $10,515,973$ & 1996-2016 & 80,536 & 171,718 & 252,253 & 542.3 \\
\hline Niger & $17,138,707$ & 1995-2016 & 31,344 & 151,468 & 182,811 & 290.8 \\
\hline Gabon & $1,802,278$ & 1993-2009 & 80,481 & 89,008 & 169,489 & 409.0 \\
\hline Gambia & $1,882,450$ & 1995-2016 & 8497 & 111,937 & 120,433 & 88.6 \\
\hline Cape Verde & 491,875 & 1997-2017 & 22,013 & 96,638 & 118,651 & 339.4 \\
\hline Burundi & $9,823,828$ & 1993-2017 & 34,921 & 66,552 & 101,473 & 187.5 \\
\hline Total & $856,671,366$ & & $86,142,982$ & $31,503,082$ & $117,646,056$ & $194,589.9$ \\
\hline
\end{tabular}

a Population source: Answers Africa [30]

b Approx. value is based on the reported data in the Comtrade database

Case studies of some countries in Africa were used to propose plastic sufficiency scenarios. Field studies embarked upon include visits to dumpsites to assess waste compositions and waste plastics scavenging activities. In the current assessment, synthetic fibres imported in synthetic textiles and synthetic carpets to Africa were not assessed by import statistic but only by literature data. In this paper, the term 'plastic' is sometimes used as a general term to cover both polymers (i.e. virgin unprocessed polymeric materials in primary forms) and finished plastic products. All currencies are in United States Dollar (\$).

\section{Results and discussion \\ Polymers consumption in Africa \\ Plastic consumption in Africa in 2015}

The per capita plastic consumption in Africa in 2015 was $16 \mathrm{~kg}$ [27] for a population of 1.22 billion [28]. Based on this, the estimated plastic consumption for the entire continent for 2015 was 19.5 Mt. For the 33 
countries considered and assessed in more detail in this study because they had consistent plastic import data in the Comtrade database (Table 2), the 2015 cumulative population was $856,671,366$ (i.e. $70.22 \%$ of African population in 2015). Considering the above per capita plastic consumption (16 kg/year), the 33 countries used approximately $13.71 \mathrm{Mt}$ of plastics in the year 2015. Consumption by the other 21 mostly smaller African countries (out of 54 countries) was approx. 3-6 Mt in 2015.

Available literature shows that GDP has a strong impact on plastic consumption [8], which can also be seen for African countries. For instance, the yearly per capita plastic consumption for 2009-2015 in Nigeria, Kenya and Ghana was 4.4-8 kg/year; while in Algeria, Egypt and Morocco, it was $13-19 \mathrm{~kg} /$ year, and $24.5 \mathrm{~kg} /$ year in South Africa [29].

As mentioned earlier, synthetic fibres (polyester, nylon, polyamide) imported as textiles and carpets into Africa were not assessed by import statistic. The current estimate from a textile fibre industry association is that Africa had a consumer demand of $5 \mathrm{~kg}$ synthetic fibres per person in 2014 [31], which would amount to $6.08 \mathrm{Mt}$ for entire Africa. Due to the contribution of synthetic fibres to micro-plastic pollution in water [32, 33], a more detailed assessment is needed for this category in future.

\section{Estimate of total historic consumption of plastic (1990-2017)}

A compilation of plastic importations for the 33 African countries between 1990 and 2017 is shown in Table 2 . The other 21 countries had only limited records and an extrapolation from the 33 countries seemed more appropriate.

The total volume of plastic importation for the selected 33 African countries was approximately $117.6 \mathrm{Mt}$ (translating to $\$ 194.6$ billion), consisting of approximately 86.14 Mt of polymers (all polymers in categories HS 3901-3914) and 31.50 Mt as plastic products (categories HS 3915-3926), spanning a period from 1990 to 2017 (approx. 27 years). Recalculating from the 33 countries to the continental level shows that roughly $172 \mathrm{Mt}$ of plastics (consisting of $126 \mathrm{Mt}$ of primary and $46 \mathrm{Mt}$ plastic products) were imported between 1990 and 2017.

One general observation is that plastics are imported at higher amounts in primary form than as finished products. This implies that the rates of plastic processing and production activities using imported primary polymers are high in many countries of Africa.

It needs to be stressed that plastic components of products such as cars, electronics, and sport equipment were not considered although these plastic sources contribute significantly to national consumption. For example, in Nigeria, these sources accounted for approximately 5.55 Mt for the years 1996-2014 compared to 17,620 Mt of primary plastics and plastic products imported for the same period [25]. Since there are insufficient data for the robust estimation of these uses in many African countries, a brief discussion of this is presented in the section on the relevance of "secondary plastic".

The current study shows massive plastic consumption (virgin polymers and finished plastic products) in Egypt, Nigeria, South Africa, Algeria, Morocco and Tunisia (in decreasing order). These six countries have contributed a significant share of the continental consumption. This observation is in agreement with the data reported for recent years by EUROMAP [29] (see Table 3). However, the EUROMAP import estimates for Nigeria and Egypt did not reflect the particularly high import data for selected years as observed in the Comtrade database. This may indicate that the exceptionally high data reported for some years in the Comtrade database might have higher uncertainties. Weight data are more prone to uncertainties compared to the monetary value of imports, since national customs are more interested in the later [34].

The six countries (Egypt, Nigeria, South Africa, Algeria, Morocco, and Tunisia) accounted for about $74.6 \%$ (approximately $87.7 \mathrm{Mt}$ ) of the polymers and plastics consumption in the 33 African countries. Compared to the estimated consumption (172 Mt) for the entire continent, these six countries accounted for $51 \%$ of the total African plastics consumption.

Geyer et al. [2] carried out a study of global material flow of virgin polymers and plastics ever produced up to the year 2015, and observed that an estimated $30 \%$ are in current use; while of the remaining quantities that have reached end-of-life, $12 \%$ were incinerated, $9 \%$ were recycled, and $79 \%$ were discarded and have accumulated in landfills or in the natural environment. However, these proportions differ from one country to another. Assuming these proportions are true for Africa, then out of the 117.6 Mt consumed within the investigated period (1990-2017), 35.3 Mt are in current use; while 82.4 Mt of waste plastic have been generated or are at their end-oflife (EoL). At EoL most plastic in Africa end up at dump sites with frequent open burning. A thorough assessment of the management and material flows of plastics is needed for Africa. This is currently at its formative stage with supports from the Basel, Rotterdam and Stockholm Conventions.

A previous study estimated the total mismanaged plastic waste in the continent of Africa in 2010 alone at 4.4 Mt [9]. The forecast in this study for the most importing countries in Africa is that the imports would have doubled by 2030. Based on this, the next decade (2020-2030) would witness about $164.7 \mathrm{Mt}$ of plastics reaching their EoL in Africa. Without proper waste management plan and strategy, the global consequence is that there would 
Table 3 Plastics resin production and consumption in 8 African countries. Source: adapted from EUROMAP [29]

\begin{tabular}{|c|c|c|c|c|c|c|c|c|}
\hline Country/period & 2009 & 2010 & 2011 & 2012 & 2013 & 2014 & 2015 & Total \\
\hline \multicolumn{9}{|c|}{ Plastics production (kt) } \\
\hline Algeria & 41 & 43 & 14 & 18 & 32 & 28 & 17 & 193 \\
\hline Egypt & 421 & 411 & 463 & 548 & 578 & 786 & 770 & 3977 \\
\hline Ghana & 0 & 1 & 1 & 2 & 2 & 2 & 3 & 11 \\
\hline Kenya & 0 & 0 & 0 & 1 & 1 & 1 & 3 & 6 \\
\hline Morocco & 47 & 53 & 53 & 60 & 61 & 62 & 60 & 396 \\
\hline Nigeria & 213 & 260 & 303 & 335 & 390 & 396 & 411 & 2308 \\
\hline South Africa & 1252 & 1229 & 1202 & 1292 & 1282 & 1362 & 1368 & 8987 \\
\hline Tunisia & 0 & 0 & 2 & 2 & 3 & 3 & 4 & 14 \\
\hline \multicolumn{9}{|c|}{ Plastics consumption per capita (kg/capita) } \\
\hline Algeria & 12.6 & 13.2 & 14.4 & 15.7 & 18.1 & 19.0 & 20.9 & \\
\hline Egypt & 13.0 & 14.6 & 14.8 & 15.5 & 15.7 & 15.0 & 15.7 & \\
\hline Ghana & 5.7 & 5.7 & 6.0 & 6.1 & 6.7 & 6.9 & 7.4 & \\
\hline Kenya & 5.1 & 5.6 & 6.0 & 6.3 & 6.9 & 8.0 & 8.2 & \\
\hline Morocco & 14.9 & 14.5 & 15.2 & 16.0 & 16.6 & 17.1 & 18.3 & \\
\hline Nigeria & 4.4 & 4.6 & 4.9 & 5.0 & 5.4 & 5.8 & 6.0 & \\
\hline South Africa & 24.0 & 24.8 & 24.6 & 24.8 & 24.2 & 24.6 & 24.7 & \\
\hline Tunisia & 21.2 & 22.1 & 23.0 & 24.4 & 26.1 & 25.6 & 25.8 & \\
\hline \multicolumn{9}{|l|}{ Plastics import (kt) } \\
\hline Algeria & 430 & 429 & 527 & 555 & 683 & 709 & 817 & 4150 \\
\hline Egypt & 898 & 969 & 993 & 1054 & 1184 & 1066 & 1136 & 7300 \\
\hline Ghana & 141 & 126 & 145 & 148 & 173 & 181 & 199 & 1113 \\
\hline Kenya & 202 & 227 & 210 & 212 & 296 & 353 & 314 & 1814 \\
\hline Morocco & 433 & 388 & 445 & 467 & 490 & 505 & 421 & 3149 \\
\hline Nigeria & 609 & 656 & 584 & 579 & 617 & 702 & 754 & 4501 \\
\hline South Africa & 323 & 401 & 420 & 459 & 423 & 439 & 250 & 2715 \\
\hline Tunisia & 224 & 238 & 241 & 259 & 284 & 279 & 286 & 1811 \\
\hline \multicolumn{9}{|l|}{ Plastics export (kt) } \\
\hline Algeria & 0 & 0 & 0 & 0 & 0 & 0 & 0 & 0 \\
\hline Egypt & 252 & 247 & 253 & 283 & 368 & 569 & 511 & 2483 \\
\hline Ghana & 1 & 0 & 0 & 0 & 0 & 1 & 0 & 2 \\
\hline Kenya & 3 & 2 & 2 & 2 & 1 & 1 & 0 & 11 \\
\hline Morocco & 5 & 5 & 5 & 4 & 3 & 3 & 0 & 25 \\
\hline Nigeria & 21 & 49 & 33 & 23 & 8 & 2 & 1 & 137 \\
\hline South Africa & 357 & 379 & 339 & 465 & 421 & 477 & 348 & 2786 \\
\hline Tunisia & 4 & 5 & 5 & 2 & 3 & 1 & 4 & 24 \\
\hline
\end{tabular}

be accumulation of billions of tonnes of plastics across terrestrial and aquatic ecosystems in the nearest future [2]. We are witnessing significant increases in marine plastic litter, with negative consequences on the ecology. The time to act is now. Egypt, Nigeria, South Africa, Algeria, and Morocco were estimated to be among the top 20 countries around the world contributing to marine debris each year [9].

\section{Time trend of plastic import to selected African countries} For the six countries with the highest share of plastic use in Africa (Fig. 1), the historic trend and projected consumption until 2030 are documented. For the projected consumption, the growth rate of the historic trend is considered a 'business as usual' model (with no anticipated change in policy, use, and attitude towards waste) as a rough basis not only for the pollution potential but also considering the waste to energy or recycling potential. 


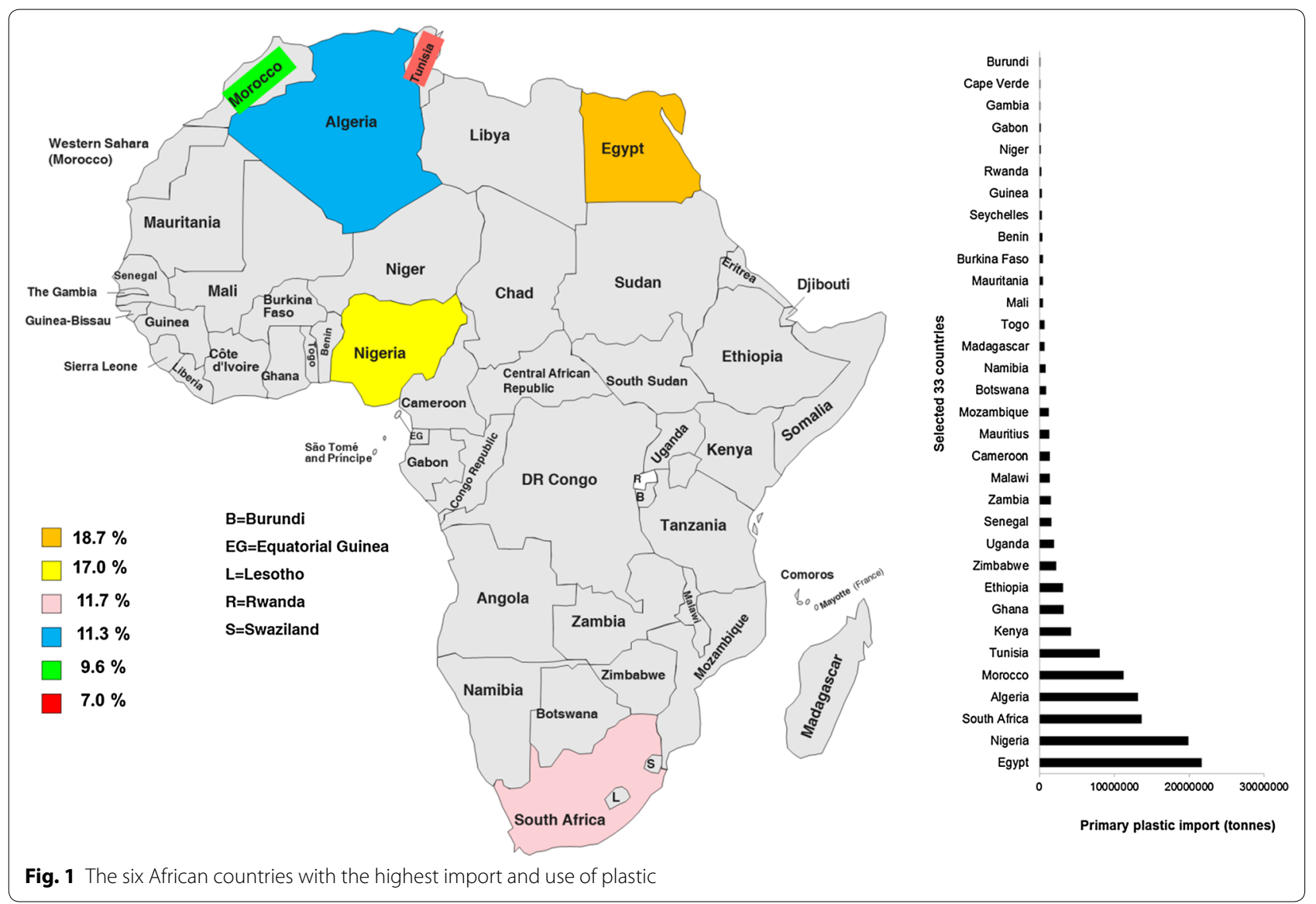

Fig. 1 The six African countries with the highest import and use of plastic

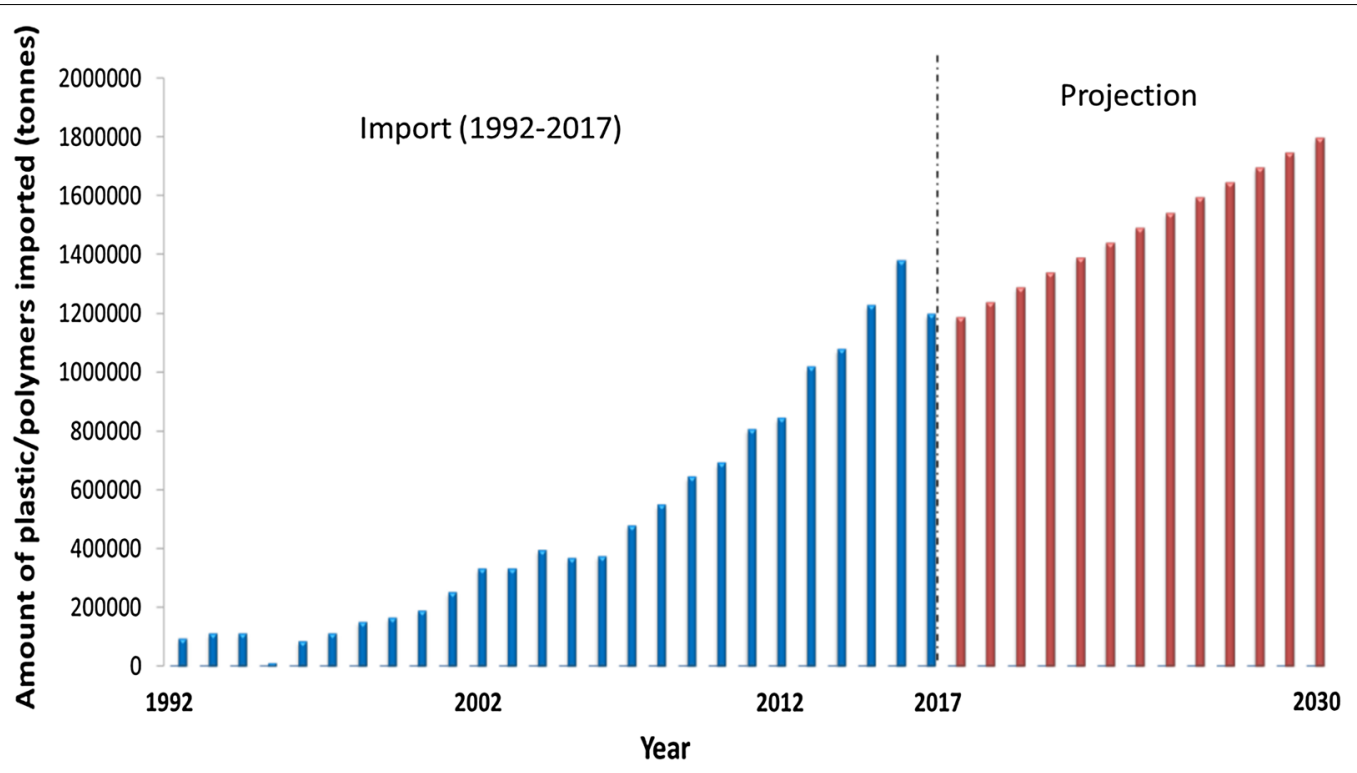

Fig. 2 Time trend of plastic/polymer import into Algeria 


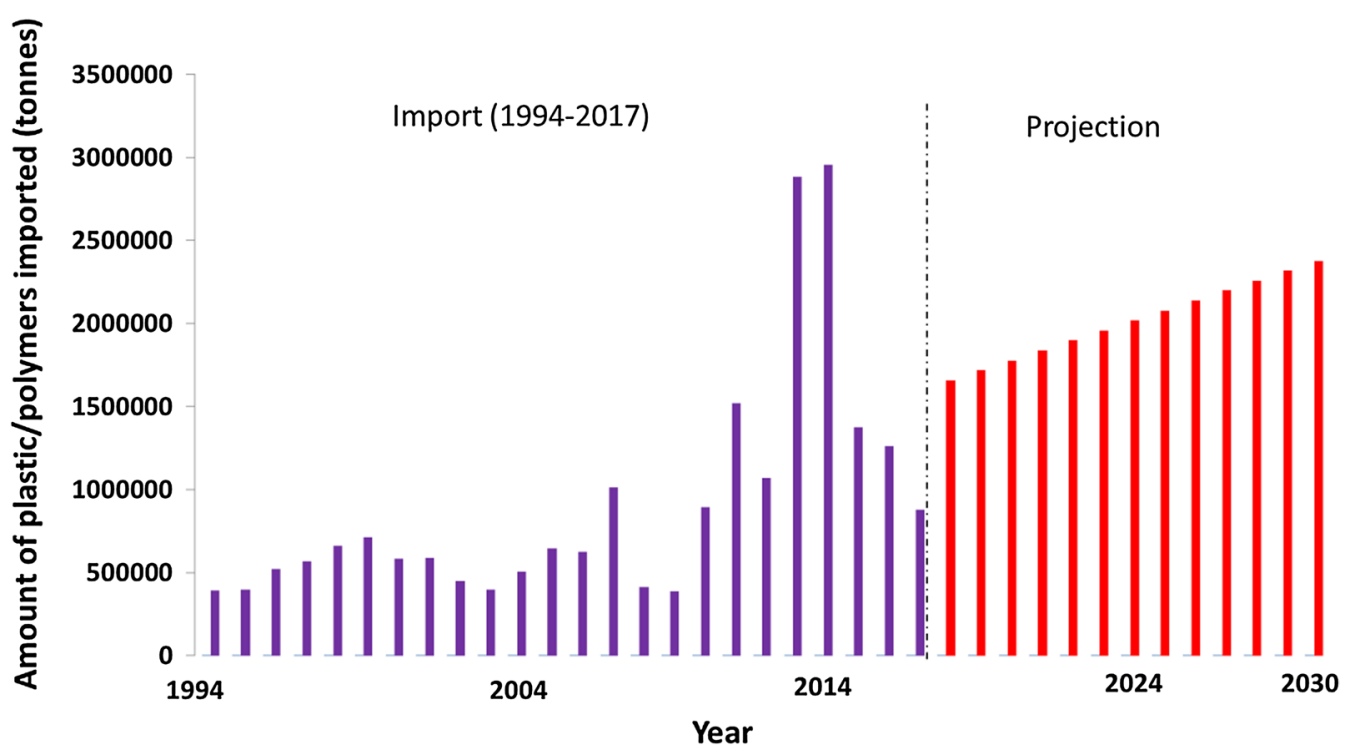

Fig. 3 Time trend of plastic/polymer import into Egypt

\section{Time trend of plastic imports and projected plastic import}

Algeria The time trend for plastics imports in Algeria shows a consistent $\left(R^{2}=0.9025\right)$ yearly increase (Fig. 2$)-$ from an import of $0.096 \mathrm{Mt}$ in 1992 to approximately 1.38 Mt in 2016. From 1992 to 2017, approximately $13.14 \mathrm{Mt}$ were imported (valued at $\$ 23.2$ billion) and this makes up about $11.2 \%$ of the whole primary plastics importation in Africa (see Additional file 1: Table S1). This, therefore, translates to $31 \mathrm{~kg} / \mathrm{cap} /$ year considering the inventory of 2015 when 1.23 Mt were imported. By 2030, with the increasing trend (business as usual), a total of $32.43 \mathrm{Mt}$ would have been imported, implying that by 2030, the plastic importation would be more than double the current amount. Plastics constitute $11-13 \%$ of municipal solid waste (MSW) in Algeria [35]; while an estimated $0.52 \mathrm{Mt}$ of waste plastic are mismanaged yearly in the country, with 70,000-190,000 tonnes constituting marine debris [9].

Egypt Presented in Fig. 3 is the time trend of imports of plastics in Egypt. In 1994, the country imported 0.39 Mt of polymers and plastics. Since then, the rate of import has increased, with massive importations in 2013 and 2014 (approx. 2.88 Mt and 2.96 Mt, respectively) amounting to about $30 \mathrm{~kg} / \mathrm{cap} /$ year in just about two decades after the first available record. From 1994 to 2017, the total importation is about $21.7 \mathrm{Mt}$ and this contributed about $18.4 \%$ of the total consumption of the selected 33 countries (also roughly $18.7 \%$ of total consumption in the African continent). The amount of plastics imported translates to $\$ 37$ billion (see Additional file 1: Table S2). By 2030 with the current trend, a total of approximately 47.9 Mt would have been shipped and consumed in Egypt, which is more than double the current amounts. Currently, plastic constitutes about 13\% of MSW in Egypt. Available statistics show that more than $80 \%$ of the MSW generated in Egypt is dumped, while the recovery rate is about $11.5 \%$ [36]. The average MSW generation rate in Egypt is about $200-250 \mathrm{~kg} / \mathrm{cap} / \mathrm{year}$. If we assume a lower value of $200 \mathrm{~kg}$ and $13 \%$ plastics composition, this would amount to $26 \mathrm{~kg}$ plastics/cap/year. The slight difference (between the per capita consumption and waste generation) may just imply that more plastics are going into stock (current use or stored). The amount of mismanaged waste plastics in Egypt is estimated at $0.97 \mathrm{Mt} /$ year, with $0.15-0.39 \mathrm{Mt}$ constituting plastic marine debris [9]. Thus, in the last decade, over 9.7 Mt may have been mismanaged in Egypt.

Morocco There was a linear time trend $\left(R^{2}=0.9785\right)$ with considerable yearly increase for Morocco (Fig. 4). In 1993, the amount imported was $0.16 \mathrm{Mt}$ and this increased consistently, reaching a peak in 2015, with approximately 0.86 Mt. From 1993 to 2016, about 11.28 Mt (valued at \$21.5 billion) were imported, accounting for $9.6 \%$ of the continental consumption (see Additional file 1: Table S3). This gives a per capita value of $26 \mathrm{~kg} / \mathrm{cap} /$ year for 2015 . Considering this trend, by 2030, the total importation would be close to $26.21 \mathrm{Mt}$.

Nigeria The time trend for Nigeria showed an increasing importation (Fig. 5). There were periods of high imports compared with the first available recorded annual import. 


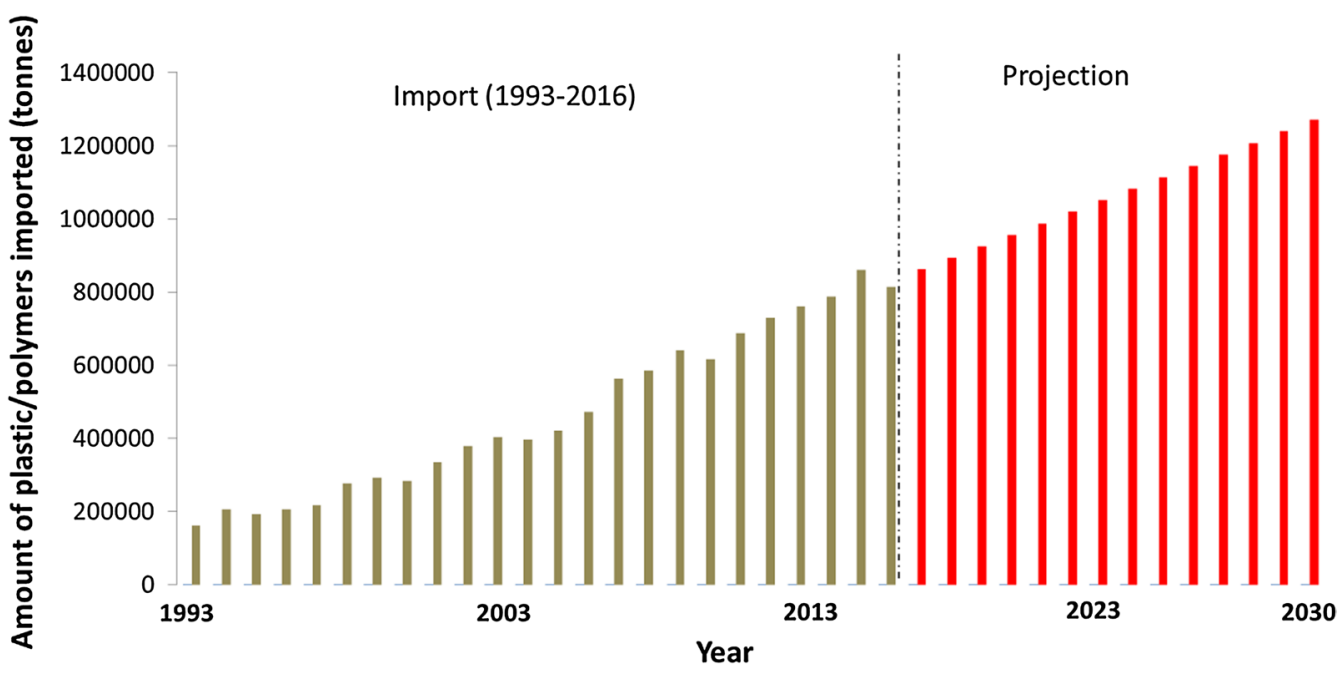

Fig. 4 Time trend of plastic/polymer import into Morocco

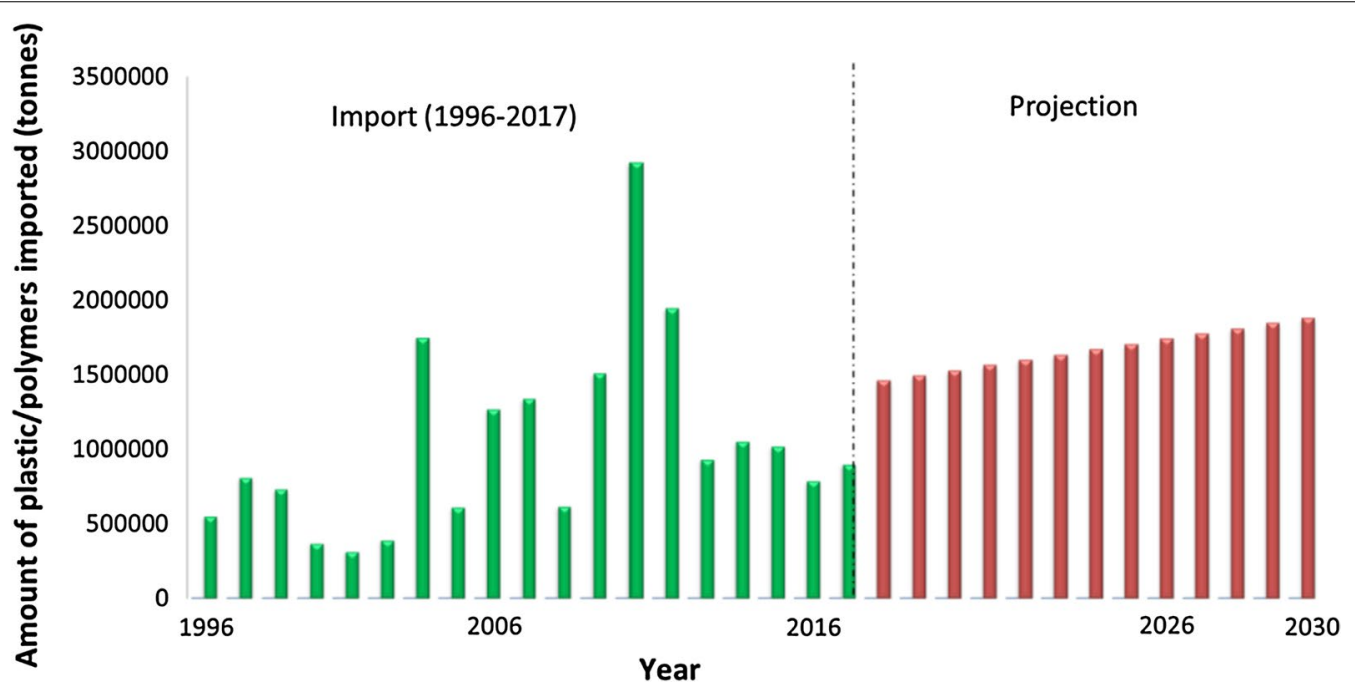

Fig. 5 Time trend of plastic/polymer import into Nigeria

In 1996, the import was 554,513 tonnes; while the highest yearly import was for 2010 (17 kg/cap/year) - approximately 2.93 Mt (see Additional file 1: Table S4). Reasons for these high imports were reported in Babayemi et al. [25]; prominent among these were imports of polymer materials for construction including roofing sheets, PVC tanks, PVC tiles, and PVC plumbing materials. From 1996 to 2017 , about $19.87 \mathrm{Mt}$ (valued at $\$ 23.1$ billion) were imported into Nigeria accounting for about $16.9 \%$ of the total consumption in Africa. Therefore, by 2030, plastics importation and consumption would likely double to a total of $41.57 \mathrm{Mt}$. Available information shows that waste plastics constitutes about $13 \%$ of MSW in Nigeria.
With approximately $0.85 \mathrm{Mt}$ of waste plastics mismanaged yearly, between 0.13 and $0.34 \mathrm{Mt}$ find their way into water bodies [9]. Available literature reported $0.58 \mathrm{~kg} /$ cap/day of MSW generation [37], and hence $212 \mathrm{~kg} / \mathrm{cap} /$ year. Assuming a plastic fraction of $13 \%$, this would mean about $28 \mathrm{~kg} / \mathrm{cap} /$ year. Considering Lagos, which is a major municipality in Nigeria, the MSW generation is $0.95 \mathrm{~kg} /$ cap/day [38], meaning $347 \mathrm{~kg} / \mathrm{cap} /$ year. For Lagos, the plastic waste generation might be as high as $45 \mathrm{~kg} / \mathrm{cap} /$ year. It is expected that considerable additional plastics are imported, e.g. via final products or as component of products like toys, electrical and electronic equipment (EEE) and vehicles [25]. This is further discussed in the sections 


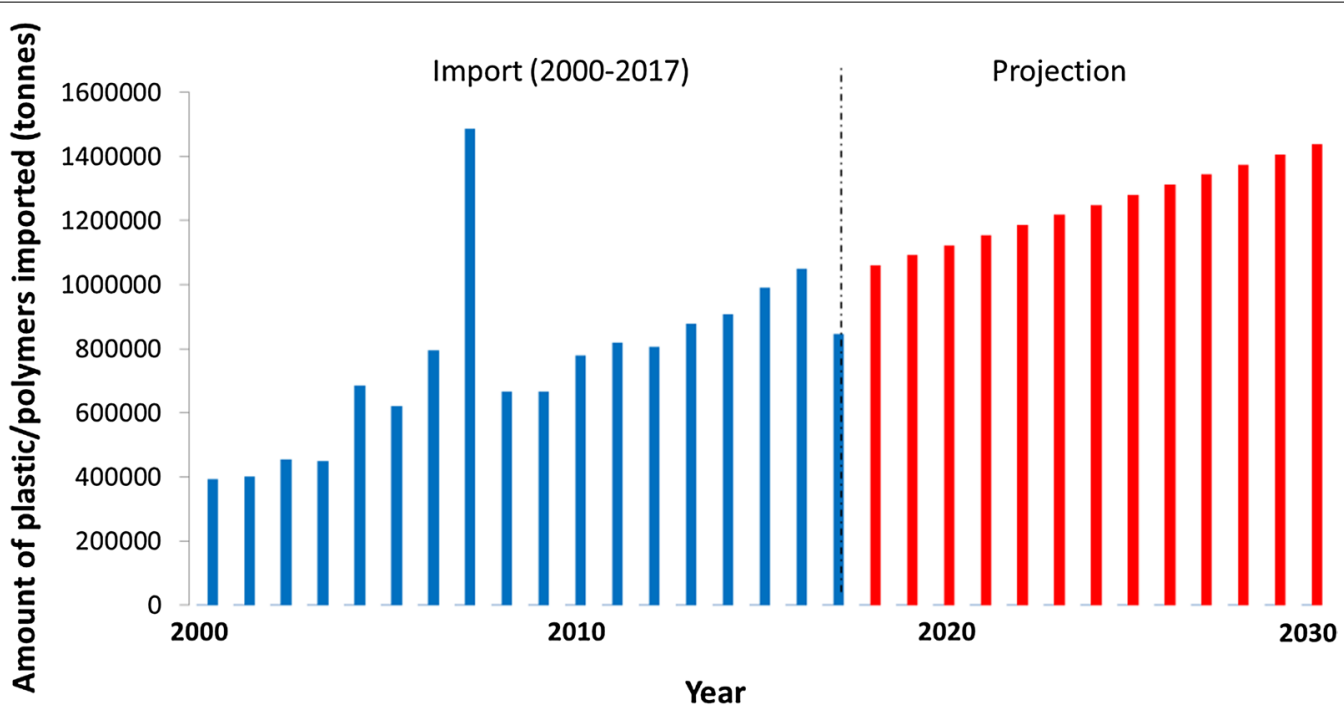

Fig. 6 Time trend of plastic/polymer import into South Africa

below. Consequently, in the last decade, the total amount of mismanaged waste plastics in Nigeria is estimated at about $8.5 \mathrm{Mt}$. Less than $12 \%$ of this is recycled, while the rest end up at open dumps before scavengers can initiate recovery within the informal sector [25].

South Africa In the year 2000, South Africa imported $0.39 \mathrm{Mt}$ of polymers and plastic (Fig. 6). The time trend of plastics importation and consumption in the country is fairly linear with a maximum of $1.49 \mathrm{Mt}$ in 2007 $\left(R^{2}=0.853\right.$, excluding the elevated import of 2007). Plastic consumption reached $18 \mathrm{~kg} / \mathrm{cap} /$ year in 2015 based on only import data and $24 \mathrm{~kg}$ if the local primary production is also considered (see below paragraph on primary production and Table 3). Between 2000 and 2017, a total of about $13.7 \mathrm{Mt}$ (estimated worth of $\$ 28.3$ billion) of plastics were imported into South Africa and this constituted about $11.6 \%$ of plastics consumption in Africa (see Additional file 1: Table S5). By 2030, an estimated 29.9 Mt (i.e. double the total current amount) would have been imported. Available statistics show that waste plastics constitutes about $12 \%$ of MSW in South Africa, which amounts to 630,000 tonnes mismanaged waste plastics per year; of which 90,000-250,000 tonnes constitute marine debris [9]. It may be inferred that in the last 10 years, over 6.30 Mt of waste plastics were mismanaged in the country. The MSW generation in the country is $2 \mathrm{~kg} / \mathrm{cap} /$ day [38]. According to ESI Africa [39], 1.144 Mt plastic wastes were generated in South Africa in 2017.

Tunisia Considering Tunisia, the yearly import also increased linearly $\left(R^{2}=0.8845\right)$ from 95,593 tonnes in
1991 to a peak of 588,210 tonnes in 2012 (Fig. 7). From 1991 to 2017 , an estimated 8.07 Mt (valued at $\$ 17.8$ billion) was consumed in Tunisia (see Additional file 1: Table S6). This amounts to $6.9 \%$ of the total consumption in Africa. It is projected that by 2030, a minimum of 16.12 Mt would have been imported and consumed in Tunisia.

While the increasing trends may generally be typical for other countries in Africa, Rwanda demonstrates that with bans, restrictions and strict enforcements, a significant reduction of plastic import and use can be achieved (see sections below).

\section{Levels of polymer categories imported}

Considering the cases of the six higher importing countries (Egypt, Nigeria, South Africa, Algeria, Morocco and Tunisia), general observation showed that polymers/ plastic in categories HS3901 to HS3907 and, HS3917 to HS3926 were imported more than the others (Fig. 8). The most prominent were polymers of ethylene in primary forms (HS3901), polymers of propylene or other olefins in primary forms (HS3902); polyethers, epoxides and polyesters in primary forms (HS3907); polymers of vinyl chloride, etc., in primary forms (HS3904); and polymers of styrene in primary forms (HS3903). HS3901 was approximately 21.19 Mt; HS3902, 16.04 Mt; HS3907, 11.05 Mt; HS3904, 8.36 Mt; and HS3903, 4.80 Mt (Fig. 8).

\section{Gaps and inconsistency of import data}

There were some gaps and inconsistencies in the data accessed. While this study tries to cover a period from 1990 to 2017, where major plastic import and use 


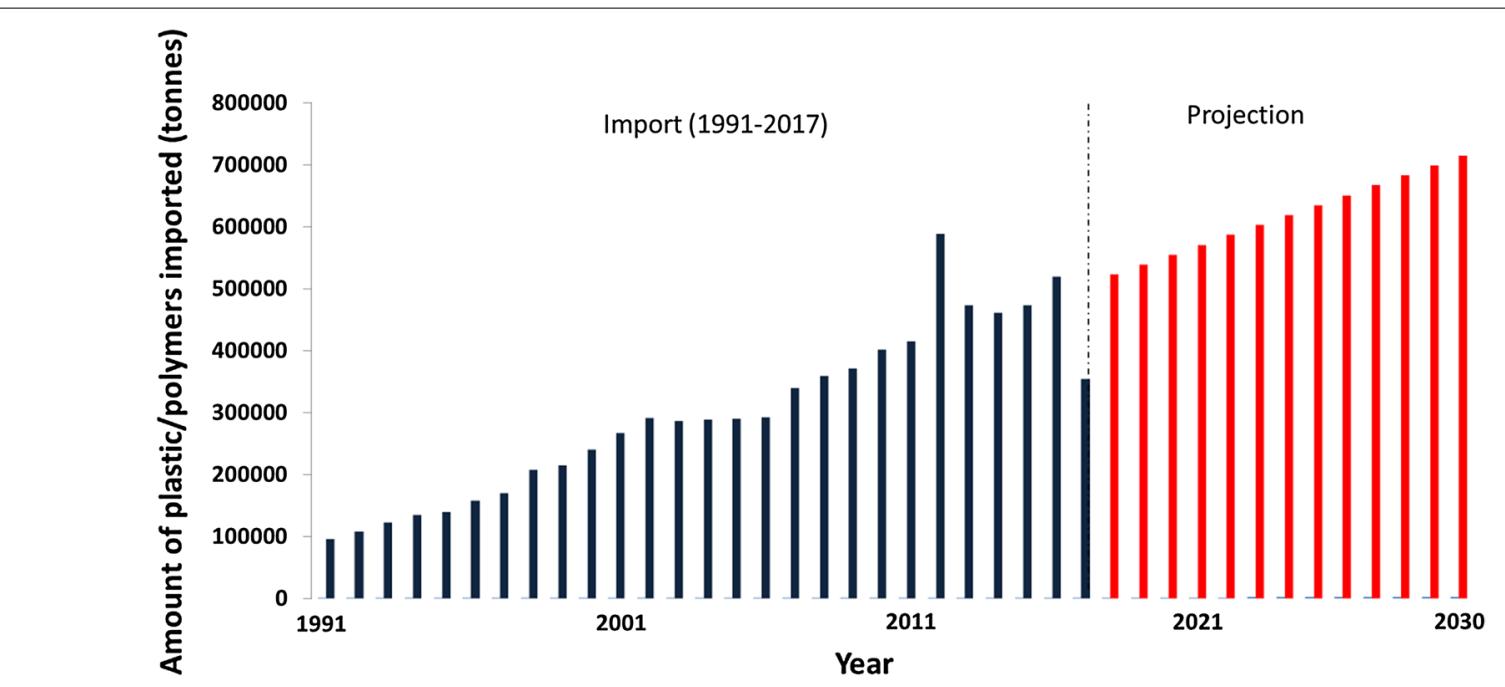

Fig. 7 Time trend of plastic/polymer import into Tunisia

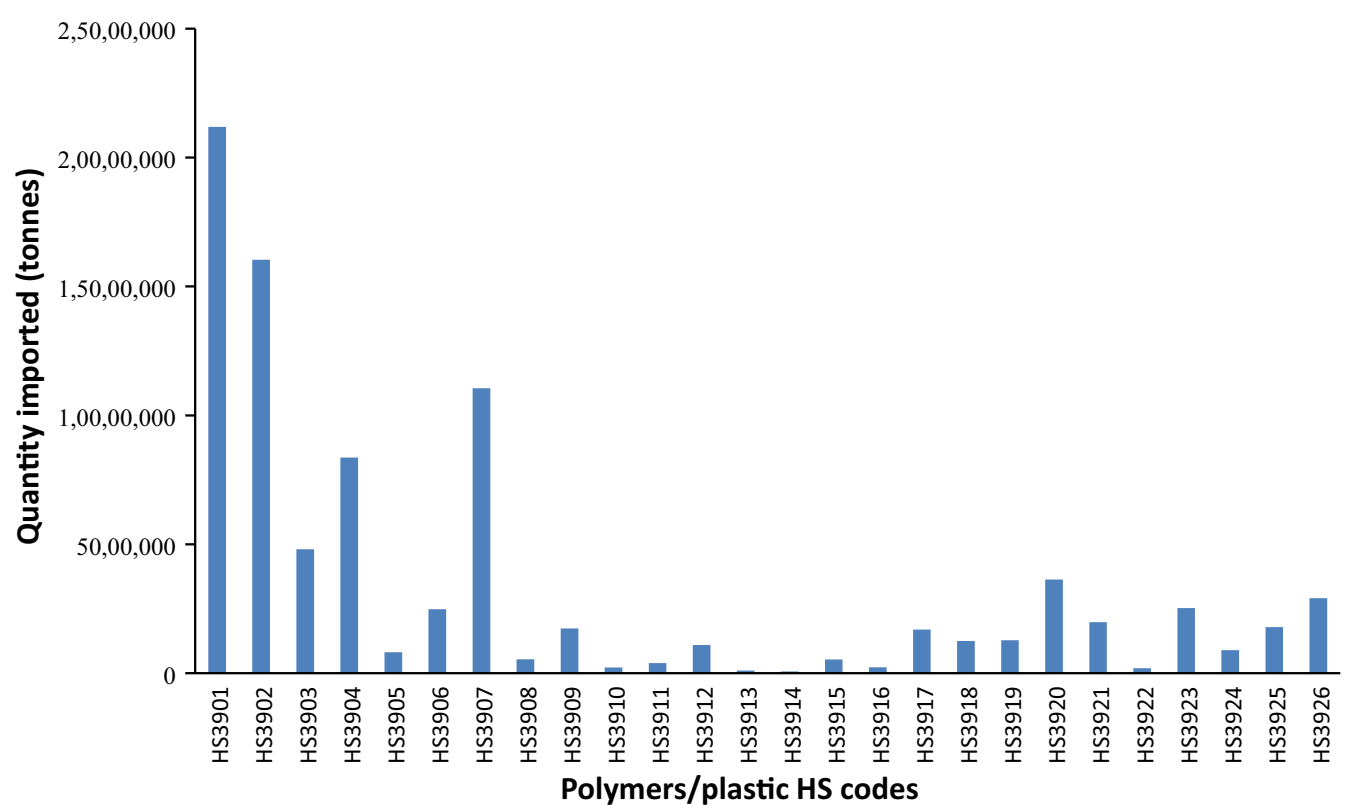

Fig. 8 Importation of polymers/plastic categories for six major consuming countries (Egypt, Nigeria, South Africa, Algeria, Morocco and Tunisia) from 1990 to 2017

occurred in Africa, not all the countries had records of up to 27 years. Most of the countries had import records of less than 20 years. Furthermore, the study covered 33 countries in Africa (only those with up to 10-year records were considered).

Also, the categories of plastics or polymers which are components of 'plastic products' especially where plastic blends were used or for products that contain mixtures of plastics (e.g. electronics), were not considered in this first attempt of an overall inventory. Some of the product types not considered could constitute a significant share of plastics imports. This is demonstrated for the case of Nigeria (see sections below) but could not be reliably estimated for the entire continent due to peculiarities of the countries (e.g. Nigeria is a major destination for used electronics and e-waste meant for reuse and recycling).

In addition detailed treatise of evaluation of data for reliability, gaps and inconsistency in UN Comtrade 
have been reported in previous studies [25, 34]. United Nations Commodity Trade Statistics Database (UN Comtrade) contains annual trade data from 1962 to the most recent years and is continuously updated. Trade data are received from national authorities of countries and are standardised by the UN Statistics Division before being added to the UN Comtrade. However, some countries do not necessarily report data for each and every year. Since UN Comtrade does not contain estimates of missing data, trade data for such countries could be underestimated. A recent study also stressed the uncertainties in UN Comtrade data with a higher risk of error in the physical weight data since the data are compiled for monetary trade information [34].

\section{Uncertainties in HS data and the method}

There are likely sources of uncertainties in a study such as this. One main source is uncertainties in UN Comtrade data. These data are compiled by countries. Predominantly, import duties and volumes are defined using the monetary value of trade and not the physical weight. Thus, the customs offices collate and gather accurately the monetary volume of trade flows as it matters for the implementation of trade policies. Therefore, information on physical weight may not be considered as important, since uncertainties in physical weights of goods do not have any consequences for the customs [34]. Reliable information from an expert who worked several years for Germany's statistical office gives credence to this-thus, this is the most important reason why monetary trade data are better than physical trade information. Therefore, deviations in physical weight are often higher than monetary values [34].

Another source of uncertainty is illegal trade. The volume of illegal trade cannot be estimated but might be considered low for such commodities. Also unregulated trades through porous land boarders and within some regional trade zone (e.g. ECOWAS) could be hidden from national statistics. It is also anticipated that the export of waste plastics from developed countries into developing countries would increase since China stopped the importation of waste plastics for recycling [40, 41].

\section{Sources of major plastics/polymers import and plastic in products: the case of Nigeria}

The major plastic materials imported into Nigeria (Fig. 9) are the primary polymers (HS codes 3901-3914) estimated at $15.8 \mathrm{Mt}$; while plastic products (HS codes 39153926) accounts for about $4 \mathrm{Mt}$. Considering the case study of Nigeria [25], the primary polymers and plastic as product were $75 \%$ of total plastic imported to the country. The primary polymers are used mostly in the production of packaging materials and household items such as kitchen utensils, chairs, tables, foot wears, etc. The second and third largest plastic consumption is in imported products such as vehicles and electronics. These are not imported under a plastic-related HS code and amounted to approximately $2.9 \mathrm{Mt}$ and $2.6 \mathrm{Mt}$, respectively (vehicles and electronics) [25]. These types and volumes of plastic are otherwise not considered in this inventory overview. Therefore, the overall plastic import to Africa could be considerably larger than the estimated in this report, considering volumes from primary imports and imports of plastic products as well as considering also importation of products containing plastic but not included in plastic product HS codes ("secondary plastic", e.g. EEE, motor vehicles and toys; Fig. 9). For Nigeria the "secondary plastic" imported in these products was $24 \%$ of total plastic when considering these major sources (where primary plastic is $75 \%$ ). Considering a similar share of "secondary plastic" in products in other African countries (if $75 \%$ primary plastic and product is $172 \mathrm{Mt}$ ) would result in an overall estimate of at least $230 \mathrm{Mt}$ plastic imported to Africa between 1990 and 2017 with contributions from Egypt, $43 \mathrm{Mt}$ (18.7\%); Nigeria, $39 \mathrm{Mt}$ (17\%); South Africa, $27 \mathrm{Mt}$ (11.7\%); Algeria, $26 \mathrm{Mt}$ (11.3\%); Morocco, $22 \mathrm{Mt}$ (9.6\%); and Tunisia, $16 \mathrm{Mt}$ (7.0\%). These include primary plastic, plastic products and major "secondary plastic". This is, however, only a crude estimate and needs to be refined in future including a refining of "secondary plastic" import assessment and a refining for the 21 countries where the database was weak.

\section{Plastics resin production and consumption in Africa}

Plastic production has been established in South Africa in the past 50 years. In 1966, South Africa's government supported the launch of a plastics industry in which Sasol [42] played a key role. In 1991, South Africa started the production of polypropylene with $120,000 \mathrm{t}$ a year and by the end of that decade, the polymer plant's annual output capacity rose to $220,000 \mathrm{t}$.

Plastics production records were obtained for eight countries in Africa (Table 3). Between the years 2009 and 2015 , the total production in the continent by the eight countries was $15.9 \mathrm{Mt}$, with the highest productions from South Africa $(9.0 \mathrm{Mt})$; followed by Egypt $(4.0 \mathrm{Mt})$ and Nigeria (2.3 Mt) [29]. These plastic producing countries also exported approximately $5 \mathrm{Mt}$.

Comparing the production of the three countries (with the far highest production volumes) with the import data from UN Comtrade (for the period 2009-2015), it shows that approximately $70 \%$ of plastic consumptions in Nigeria and Egypt in primary form and as product were imported. On the other hand, South Africa only imported $27 \%$ of primary plastic and exported $24 \%$ of locally produced plastic resins/products. Thus, South 


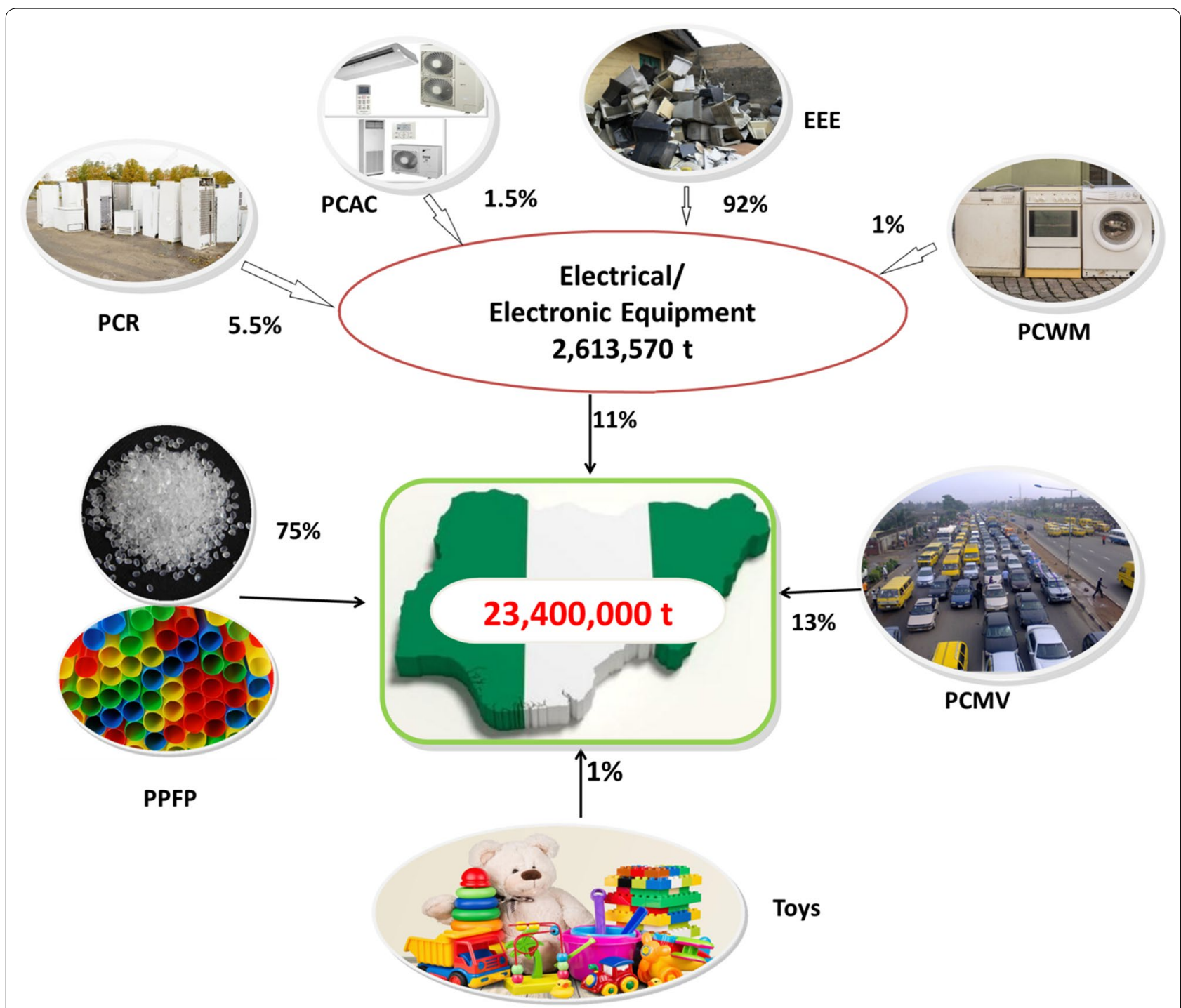

Key: Imported polymers (in primary form and as plastic products) (PPFP); Plastic components of refrigerators (PCR); Plastic components of air conditioning equipment (PCAC); Plastic components of laundry washing machines (PCWM); Plastic components of motor vehicles (PCMV); Categories 3 and 4 of European Union electrical and electronic equipment (EEE) classification; Toys (T)

Fig. 9 Major categories of plastics/polymers imported to Nigeria (1996-2014)

Africa produced and consumed a similar amount of plastic as it exported. For all other African countries with primary production, the plastic consumptions per capita derivable from Comtrade database were comparable to data reported in EUROPMAP [29].

\section{Plastic sufficiency scenario and the reduction of plastic use in Rwanda}

Publications and industry experts highlight that plastic production and consumption will increase in the next decade by as much as $40 \%$ [43]. However, considering the current plastic waste crises and that much of this plastic is not needed for a sustainable society (i.e. meeting our needs without compromising the needs of future generations), a considerable decrease in plastic use is needed. This would follow the Sufficiency Economy ${ }^{4}$ approach of just using the optimal material threshold $[44,45]$ and

\footnotetext{
${ }^{4}$ Sufficiency Economy was introduced by late King Bhumibol Adulyadej's and acknowledged by UN (Mongsawad 2010).
} 


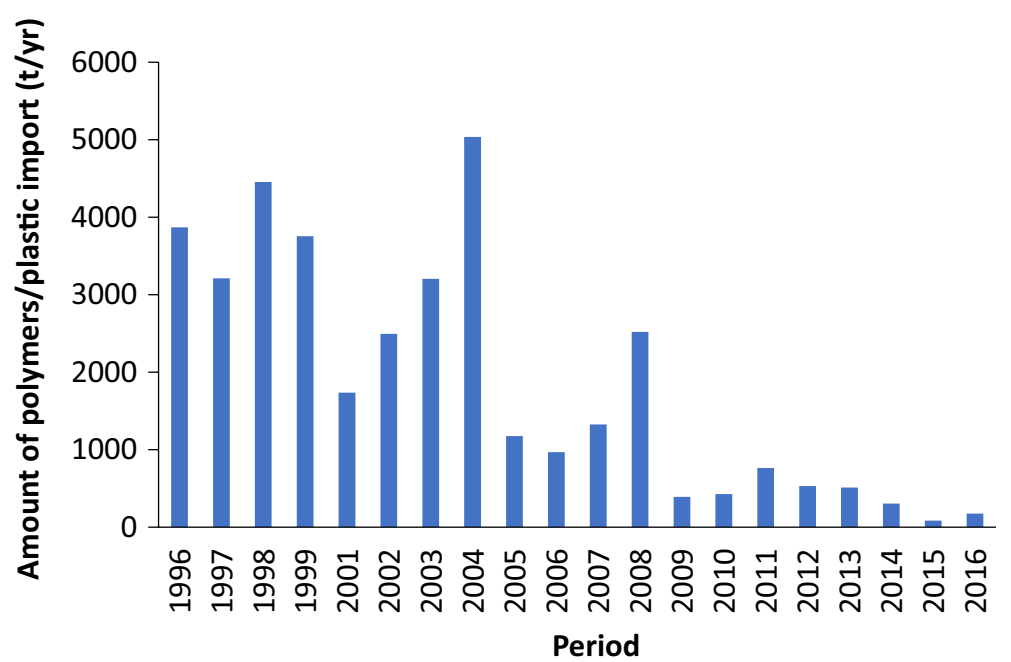

Fig. 10 Time trend of "Articles of plastics" (HS3926) imports to Rwanda (1996-2016)

supporting only the necessary uses of plastic. To achieve this, the projected growth of plastic use should be countered and rather reversed by governments (especially, the many 'single use' plastics) with appropriate policy formulations and their strict implementation. This can be achieved if some major plastic consumption routes (e.g. plastic bags) are blocked through regulations or substituted with environment friendlier alternatives [46-49].

In Rwanda, strict enforcement of regulations has reduced the use of plastic bags since 2008. Also, the import of plastic products into the country has decreased. For instance, plastics labelled as "Other articles of plastics" (HS Code HS3926) covering finished plastic articles declined from 5000 tonnes in 2004 to 175 tonnes in 2016 (see Fig. 10). On the other hand, the total primary plastic import in the country increased until 2014 and decreased thereafter (Fig. 11). The increase was triggered partly by the increasing importation of polymers of styrene in primary forms (HS3903) due to increasing demand for foam insulation-an attempt to reduce GHG emissions by reducing the need for air conditioning. However since 2015, importation of polymers of styrene in primary forms has decreased (Additional file 1: Fig. S7a) possibly due to the National Housing Policy published 03/2015, stipulating the use of local construction materials [50]. Furthermore, it can be observed from the import statistics (Additional file 1: Figure S7 and S9; Table S8) that official plastic importation and consumption has decreased. Polymers with code HS3905 (polymers of vinyl acetate and other vinyl polymers in primary forms) decreased from 532 tonnes in 2009 to 263 tonnes in 2016; HS3908 (polyamides in primary forms) decreased from 101 tonnes in 2010 to 11 tonnes in 2016; HS3910 decreased from 104 tonnes in 2012 to 13 tonnes in 2016; HS3913 (natural, including modified polymers in primary forms) decreased from 106 tonnes in 2005 to approximately zero import in 2016 (Fig. 10; Additional file 1: Figures S7 and S9; Table S8). The following also experienced a decrease in consumption: polymers of vinyl acetate and other vinyl polymers in primary form (HS3905); polyamides in primary form (HS3908), silicones in primary forms (HS3910), and "natural, including modified polymers in primary forms" (HS3913). Overall, the use of polymers from categories 3908-3916 is now at the minimum levels of the last decade.

In June 2019, Rwanda's Cabinet adopted a draft law seeking to prohibit the manufacture, use and sale of single-use plastics [51]. The reduction of single plastic use can likely further reduce the overall plastic consumption in Rwanda in the nearest future.

The example of Rwanda demonstrates the possibility to decrease the use of plastic (plastic sufficiency scenario) if decisions can be taken at national levels to cut down on the use of plastics. The experience in Rwanda contrasts with the otherwise increasing plastic consumption in other African countries (Figs. 2, 3, 4, 5, 6, 7).

On the other hand, Rwanda had at the same time in the last decade witnessed a yearly GDP increase of between 4.7 and $8.9 \%$ and an increase in per capita GDP from $\$ 1229 /$ year in 2008 to $\$ 2080 /$ year in 2017 [52]. This demonstrates that with the right policies and bans (and strict enforcement), a reduction in plastic import and use in a country is possible alongside overall industrial growth without negative impacts. 


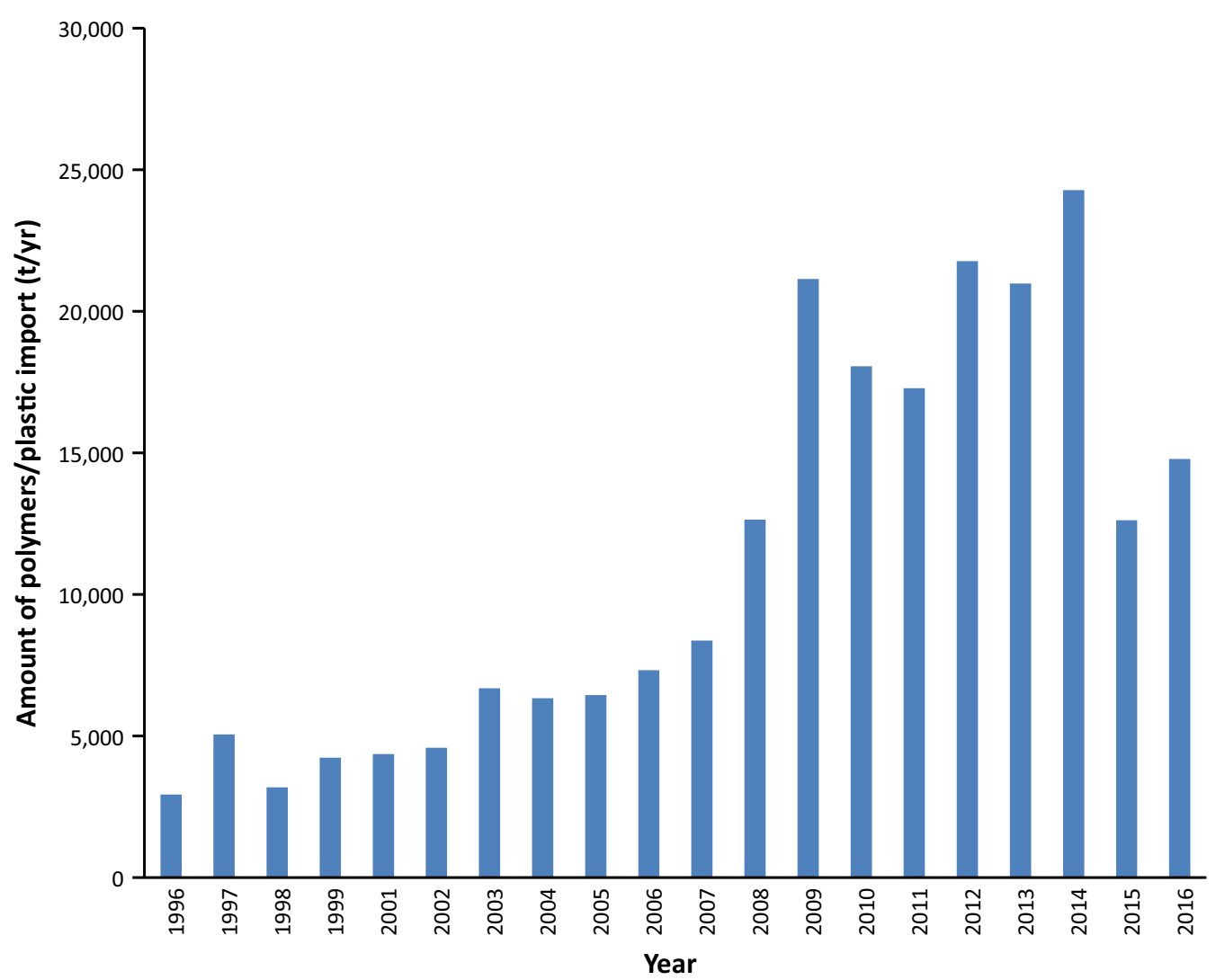

Fig. 11 Time trend of total primary polymer/plastic imports to Rwanda (1996-2016)

\section{Plastic use and the resulting wastes}

The current time trend of import in the major six plastic using African countries indicates that polymers/plastic imports will be double the current amounts by 2030 . Considering the "business as usual", by 2030, these six countries would have consumed about $175.5 \mathrm{Mt}$; while for the selected 33 countries, this would amount to 235.3 Mt and $344 \mathrm{Mt}$ for the entire continent.

Waste plastics are disposed with MSW with minimal formal recycling (approx. 10\%) [26, 53]. There is also hardly any thermal/energy recovery from waste plastic or other wastes, e.g. in incinerators or cement kilns in Africa. Consequently, virtually all waste plastics end up at dump sites (Additional file 1: Fig. S12a-d), in water ways or open burning (Additional file 1: Fig. S13).

Previous studies have shown that the most commonly used and abundant polymers are high-density polyethylene (HDPE), low-density polyethylene (LDPE), polyvinyl chloride (PVC), polystyrene (PS), polypropylene (PP) and polyethylene terephthalate (PET) [1]. It is expected that at the EoL, considerable amounts of these plastic types may constitute the bulk of disposed solid municipal wastes. In Bangkok City, the plastic components of the municipal waste were made up of HDPE, LDPE, PP, and PET accounting for 57.4\%, 17.4\%, 7.3\%, and 5.9\%, respectively; while others, PS, and PVC represented $5.0 \%$, $4.8 \%$, and $2.2 \%$ [54] which might also give an indication for other developing countries in Africa and are roughly in line with the major import HS codes in Africa. For one plastic product where large volumes are consumedsachet water-the dimension of production and current situation in two countries is described. In many African countries, sachet water industries consume a large share of polyethylene (both low-density polyethylene LDPE and the high-density polyethylene, HDPE). Considering the current population of Africa (ca. 1.3 billion), assuming each person consumes a 500-mL sachet water per day (definitely an under-estimation) with the empty weighing $\sim 1.5 \mathrm{~g}$ ), an estimated 1950 tonnes of waste polymer is generated per day; amounting to approximately 0.7 Mt/year or $7 \mathrm{Mt}$ in the last decade. In Ghana, the small scale sachet water companies produce about 45,000 sachets per day; while the bigger companies produce over 150,000 per day, making approximately 200,000 sachets per day [55]. By the year 2006, up to 40 plastic manufacturing companies were established in Ghana 
with production capacity of about 26,000 tonnes; [55]. A recent assessment has documented the agricultural pollution resulting from sachet water in Ghana [56]. In Nigeria, there are meanwhile over 1500 sachet water factories in Lagos alone; while about 60 million sachets are consumed daily, and the plastic wastes disposed especially by littering or into drainages [57]. It should be assessed if deposit schemes could be a practical option to address sachet waste. However, deposit return schemes are very rare in Africa.

MSW are not separated at source in Nigeria. Consequently considerable quantities of plastics end up at the dumpsites where it becomes fuel of landfill/dumpsite fires with associated releases and exposure [58-60]. Other plastic products have currently a similar end of life fate including the plastics and polymer foams from products such as waste from EEE (WEEE) and EoL vehicles $[26,53,61]$.

\section{Environmental pollution and human health challenges}

In addition to contamination by open dump sites (Fig. 11), the light weight of some plastic bags, plastic packaging, straws and polystyrene make it easier for winds to blow them around-eventually routing them into water bodies. Together with other waste plastic like PET bottles, they constitute a larger fraction of marine litter [62]. Recent estimates show that by the year 2025, around 250 million tonnes of plastics will be in the oceans globally [9]. More than $1 \mathrm{Mt}$ of plastic waste enter the oceans from African countries (see above section for a discussion of the 6 major plastic consuming African countries) [9]. Though it could take hundreds of years for plastics to degrade in the marine environment, they can break down into macroplastics $(>5 \mathrm{~mm})$, microplastics $(<5 \mathrm{~mm})$ and nanoplastics $(<100 \mathrm{~nm})$ which may be taken up by marine organisms along the food chain; the plastics and the hazardous constituents may pose threats to the aquatic ecosystems and eventually have negative consequence on human health [63].

Furthermore, open burning is a common solid waste management option in African countries in particular for plastic, which is a fuel for open burning on landfills and backyard waste burning [64]. Since there is no effective solid waste sorting systems; mixed wastes including plastics end up in dumpsites where they are set on fire. These open burning methods result in the release of hazardous substances into the environment as a result of the plasticizers and flame retardants used in the plastics and contaminate air and soils and food [58, 60, 65, 66].

Considering the contamination on land and marine from the mismanaged plastic in Africa, urgent improvement of the situation is needed.

\section{Waste plastic as resource}

Waste plastics may be effectively separated from the various waste streams for subsequent recycling, recovery and reprocessing [67]. When properly managed, waste plastics present potential resources. Resource recovery may be categorised into [68]:

- Mechanical recycling (primary and secondary),

- Chemical recovery (tertiary) and;

- Energy recovery (quaternary).

Though the larger share of waste plastic is still mismanaged in Africa (Additional file 1: Fig. S10), some primary and secondary recycling of certain categories of waste plastic take place. For instance, in South Africa where South African Plastics Recycling Organisation (SAPRO) is in operation since 2010, the recycling quota has reached $43 \%$ for major plastics which is higher than in Europe [69]. In South Africa, the most widely recycled material is PE-LD and PE-LLD packaging films (34\%), followed by PET beverage bottles which showed a steady increase over the last 4 years (22\%), PE-HD bottles, drums and crates represent the third largest recycled polymer in 2017 (20\%) [69]. It needs to be stressed that calculated recycling quota depends on the calculation method and are often overestimated [70]. Also in Nigeria, a large share of PET bottles is going in recycling as observed in our field survey where even PET bottles were separated on dump sites (Additional file 1: Fig. S10a). However, there is serious limitation to full recovery of PET bottles from MSW. Efficient recovery is assured if the waste PET bottles are collected 'clean' immediately after use without mixing with MSW. Consequently collectors prefer waiting at occasions such as conferences/ workshops for immediate take-back as better convergence of used PET bottles is assured. Waste PET disposed with MSW ends up 'dirty' and is less sought afterwards (Additional file 1: Fig. S10b, c).

Most categories of waste plastics are not usually sought after by recyclers in African countries. These are waste polystyrene (expanded polystyrene (EPS) and extruded polystyrene XPS), polyurethane (PUR) foam, light packaging polymers, e.g. for packaging of 'sachet water' (made from polyethylene), PVC wastes, plastic waste from EEE and plastic and polymers from EoL vehicles. The EPS/ XPS foam and PUR foam products and products made from polyamides are locally 'unrecyclable' plastic categories and are usually found in various shapes, size and colour in dumpsites (Additional file 1: Fig. S10b, c). In Africa (and other countries), EPS/XPS are used for food and other packaging and insulation foams and huge quantities are consumed annually. EPS/XPS and light 
plastic bags are massively dumped and burned at open dumpsites.

In 2017, the first African plant which converts plastic waste into synthetic fuel oil was developed in Kenya [71] and a first waste to energy plant started operation in Ethiopia [49].

Recycling of plastic waste might gain more momentum: On 26 March 2019, a group of international consumer goods companies operating across Africa and responsible for a large share of plastic pollution launched the 'African Plastics Recycling Alliance' at the seventh edition of the Africa CEO Forum [72]. The Alliance aims to transform plastics recycling infrastructure across sub-Saharan Africa.

\section{Financial implications of plastics and environmental cost}

Plastic is a huge business with large revenues. The total import for polyethylene throughout the world in 2015 was estimated at $\$ 75$ billion [73]. Currently, the annual revenue generated by the global plastic industry is about $\$ 600$ billion [6]. The estimated value of the $117.6 \mathrm{Mt}$ of polymers/plastic imported into Africa in this study is $\$ 194.5$ billion for a period of 27 years. On the other hand, Trucost [74] estimated that the environmental cost of business-as-usual plastic in consumer goods is $\$ 139$ billion in 2015 and this is expected to grow to \$209 billion by 2025 (if current trends persist). Meanwhile, substitute plastic in consumer goods will cost $\$ 533$ billion, while going for a more sustainable plastic in consumer goods will only cost $\$ 98$ Billion [74]. It implies that global and regional attention and efforts should focus on sustainable plastics.

In Africa, one key issue in the management of plastic waste is finance. One way of achieving this is through the introduction of extended producer responsibility (EPR) and imposing tax on plastic importation and production $[75,76]$. The monies realised from taxation of primary plastics and plastic products would go a long way in financing EoL management of waste plastics and provide a decent income for scavengers (waste plastic collectors) and recycler. Tax incentives (e.g. tax holidays) for plastic recyclers will encourage their activities and the acquisition of needed machinery.

Also implementing deposit systems play a crucial role in high collection rates [77].

\section{Conclusion and recommendations}

This study presents the first inventory and continental historical analysis of mass importation of polymers and plastics (in primary and secondary forms) and the associated pollution potential in Africa. This report, on one hand, can serve as a database for future studies and a preliminary data basis for estimating recycling or energy recovery opportunities. More than 117.6 Mt (translating to $\$ 194.5$ billion), consisting of approximately $86.14 \mathrm{Mt}$ of polymers in primary form and $31.50 \mathrm{Mt}$ as products entered Africa through 33 countries between 1990 and 2017. Of this amount, there were significant contributions from Egypt (18.4\%), Nigeria (16.9\%), South Africa (11.6\%), Algeria (11.2\%), Morocco (9.6\%) and Tunisia (6.9\%). It was also predicted that by 2030 approximately 235.3 Mt of polymers and plastic in these forms would be consumed in these 33 African countries if there are no policy changes (business as usual). For the entire continent, this amounts to the consumption of $344 \mathrm{Mt}$ of plastic by 2030 .

This study did not consider products containing plastics classified as "secondary plastic", e.g. EEE, motor vehicles, and toys (Fig. 9). For Nigeria, "secondary plastic" imported in these products was $24 \%$ of total plastic consumption.

Currently, all forecasts predict an increase in plastic use and production pushed by the global growth dogma (business as usual). However, there is also the sustainable alternative scenario of reduction of plastic use as illustrated by the case study of Rwanda. Rwanda has shown that with the ban of plastic bags, prohibition of single-use plastics, and use of locally produced construction materials (as substitutes to imported plastic insulation), reduction in plastic consumption could be achieved alongside increase in national GDP and GDP per capita. Thus, a significant reduction in plastics consumption can be achieved in Africa-however, this requires not just policy formulations (bans and regulations) but also their strict implementation and enforcement. The Rwandan success should be a motivation for other African countries as this is essential in achieving sustainable consumption and production (SDG 12). A more detailed assessment of how Rwanda succeeded in reducing plastic consumption should be conducted in a targeted study.

Financing waste management in Africa is a bottleneck to sustainable consumption and production and overall success of sustainable development. Considering the burden of plastic for waste management and environmental pollution, it is reasonable and important to tax plastic imports, production, and use to finance plastic waste management. Furthermore, appropriate waste management policies should be developed and enforced. Management of plastic waste is getting better in industrialised countries because there is appropriate policy in place. For instance, increasingly stringent European legislation is setting new standards that promote the application of novel recycling technologies capable of absorbing large amounts of plastic wastes [78], implementing deposit systems [77] and banning single-use plastic [47]. 
Based on inventory of plastic import and use, National Strategies need to be developed including national or regional action plans for the environmentally sound management of plastic waste.

\section{Supplementary information}

Supplementary information accompanies this paper at https://doi. org/10.1186/s12302-019-0254-5.

Additional file 1. Additional tables and figures.

\begin{abstract}
Abbreviations
EDCs: endocrine disrupting chemicals; EEE: electrical and electronic equipment; EoL: end-of-life; EPR: extended producer responsibility; EPS: expanded polystyrene; GDP: gross domestic product; HDPE: high-density polyethylene; HS: harmonised system; LDPE: low-density polyethylene; MSW: municipal solid waste; PET: polyethylene terephthalate; POPs: persistent organic pollutants; PP: polypropylene; PS: polystyrene; PVC: polyvinyl chloride; SAPRO: South African Plastics Recycling Organisation; SDGs: sustainable development goals; UNEA: United Nations Environment Assembly; UN: United Nations; US: United States; WEEE: waste electrical and electronic equipment; XPS: extruded polystyrene.
\end{abstract}

\section{Acknowledgements}

The valuable comments of Professor Hans Fellner are acknowledged.

\section{Authors' contributions}

JOB generated and analysed the data. JOB, ICN, OO and RW interpreted and discussed the data. All authors read and approved the final manuscript.

\section{Funding}

Not applicable.

\section{Availability of data and materials}

All data generated or analysed during this study are included in this published article [and its additional file].

\section{Ethics approval and consent to participate}

Not applicable.

\section{Consent for publication}

Not applicable.

\section{Competing interests}

The authors declare that they have no competing interests.

\section{Author details \\ ${ }^{1}$ Department of Chemical Sciences, Bells University of Technology, Ota, Nigeria. ${ }^{2}$ Department of Chemical Sciences, Anchor University, Lagos, Nigeria. ${ }^{3}$ Department of Pure and Industrial Chemistry, Abia State University, Uturu, Nigeria. ${ }^{4}$ Visiting Research Fellow, Manchester Institute of Biotechnology, University of Manchester, Manchester, UK. ${ }^{5}$ Jawura Environmental Services Limited, 130 Obafemi Awolowo Way, Ikeja, Lagos, Nigeria. ${ }^{6}$ POPs Environmen- tal Consulting, 73527 Schwäbisch Gmünd, Germany.}

Received: 6 July 2019 Accepted: 3 September 2019

Published online: 28 September 2019

\section{References}

1. Li WC, Tse HF, Fok L (2016) Plastic waste in the marine environment: a review of sources, occurrence and effects. Sci Total Environ 567:333-349

2. Geyer R, Jambeck JR, Law KL (2017) Production, use, and fate of all plastics ever made. Sci Adv 3(7):1-5. https://doi.org/10.1126/sciadv.1700782

3. Ratnasari DK, Nahil MA, Williams PT (2016) Catalytic pyrolysis of waste plastics using staged catalysis for production of gasoline range hydrocarbon oils. J Anal Appl Pyrol. https://doi.org/10.1016/j.jaap.2016.12.027
4. World Economic Forum (2019) Eight steps to solve the ocean's plastic problem. https://www.weforum.org/agenda/2018/03/8-steps-to-solve -the-oceans-plastic-problem/. Accessed 8 Feb 2019

5. Rokade S (2012) Use of waste plastic and waste rubber tyres in flexible highway pavements. In: 2012 International Conference on Future Environment and Energy IPCBEE vol. 28 (2012). IACSIT Press, Singapore Polymer-Plastics Technology and Engineering, vol 47, pp 741-74

6. Venkatesh S, Kukreti I (2018) An Indian consumes 11 kg plastic every year and an average American $109 \mathrm{~kg}$. Down to Earth, 06 June 2018, https:// www.downtoearth.org.in/news/waste/an-indian-consumes-11-kg-plast ic-every-year-and-an-average-american-109-kg-60745

7. Gourmelon G (2015) Global plastic production rises, Recycling Lags. Worldwatch Institute, Washington, vitalsigns.worldwatch.org

8. Jain A (2019) Reducing plastic wastes through circular economy-implications towards 12 \& 14. Presentation 9th Regional 3R Forum in Asia \& the Pacific, 4-6th March 2019, Bangkok, Thailand. http://www.uncrd.or.jp/ content/documents/7605PS-2-PPT-1.pdf

9. Jambeck JR, Geyer R, Wilcox C, Siegler TR, Perryman M, Andrady A, Narayan R, Law KL (2015) Plastic waste inputs from land into the ocean. Science 347:768-771

10. Jambeck J, Hardesty BD, Brooks AL, Friend T, Teleki K, Fabres J, Beaudoin Y, Bamba A, Francis J, Ribbink AJ, Baleta T, Bouwman H, Knox J, Wilcox C (2018) Challenges and emerging solutions to the land-based plastic waste issue in Africa. Marine Policy 96:256-263

11. GIA (Global Industry Analysis) (2008) Plastic additives: a global strategic business report (MCP-2122, GIA) https://www.strategyr.com/Plast ic_Additives_Market_Report.asp

12. Rajaram S (2009) Plastic additives: the global market (PLS022B, BCC Research). https://www.bccresearch.com/market-research/plastics/plast ic-additives-market-pls022b.html

13. Hahladakis JN, Velis CA, Weber R, lacovidou E, Purnell P (2018) An overview of chemical additives present in plastics: migration, release, fate and environmental impact during their use, disposal and recycling. J Hazard Mater 344:179-199

14. UNEP (2019) Plastic and toxic additives, and the circular economy: the role of the Basel and Stockholm Conventions. UNEP/CHW.14/INF/29/ Add.1-UNEP/POPS/COP.9/INF/28/Add.1

15. Ionas AC, Ulevicus J, Gómez AB, Brandsma SH, Leonards PE, van de Bor M, Covaci A (2016) Children's exposure to polybrominated diphenyl ethers (PBDEs) through mouthing toys. Environ Int 87:101-107

16. Nnorom IC, Osibanjo O (2008) Sound management of brominated flame retarded plastics from electronic wastes: state of the art and options in Nigeria. Resourc Conserv Recycl 52:1362-1372

17. Shaw SD, Blum A, Weber R, Kannan K, Rich D, Lucas D, Koshland CP, Dobraca D, Hanson S, Birnbaum LS (2011) halogenated flame retardants: do the fire safety benefits justify the risks? Rev Environ Health 25(4):261-305

18. Weber R, Kuch B (2003) Relevance of BFRs and thermal conditions on the formation pathways of brominated and brominated-chlorinated dibenzodioxins and dibenzofurans. Environ Int 29:699-710

19. Shea KM, the American Academy of Pediatrics Committee on Environmental Health (2003) Pediatric exposure and potential toxicity of phthalate plasticizers. Pediatrics 111 (6 Pt 1):1467-1474

20. Weber R, Fantke P, Ben Hamouda A, Mahjoub B (2018) 20 Case Studies on How to prevent the use of toxic chemicals frequently found in the Mediterranean Region. Report of the Regional Activity Centre for Sustainable Consumption and Production (SCP/RAC) an EU SwitchMed. https://www.switchmed.eu/e-library/20-case-studies-to-prevent-theuse-of-toxic-chemicals-frequently-found-in-the-mediterranean-region

21. United Nations Economic and Social Council (2009) Africa Review Report on Chemicals (Summary) E/ECA/CFSSD/6/8. https://sustainabl edevelopment.un.org/content/documents/AficanReviewReport-onChemicalsSummary.pdf

22. Webb HK, Arnott J, Crawford RJ, Ivanova EP (2013) Plastic degradation and its environmental implications with special reference to poly(ethylene terephthalate). Polymers 5(1):1-18. https://doi. org/10.3390/polym5010001

23. Shah AA, Hasan F, Hameed A, Ahmed S (2008) Biological degradation of plastics: a comprehensive review. Biotechnol Adv. 26(3):246-265. https://doi.org/10.1016/j.biotechadv.2007.12.005

24. IISD (International Institute for Sustainable Development) (2019) Summary of the meetings of the conferences of the parties to the Basel, 
Rotterdam and Stockholm Conventions: 29 April-10 May 2019. Earth Negotiations Bulletin Vol. 15 No. 269, 13 May 2019. http://enb.iisd.org/ chemical/cops/2019/

25. Babayemi JO, Ogundiran MB, Weber R, Osibanjo O (2018) Initial inventory of plastics imports in Nigeria as a basis for more sustainable management policies. J Health Pollut. 8(18):6-20

26. Babayemi JO, Sindiku O, Osibanjo O, Weber R (2014) Substance flow analysis of polybrominated diphenyl ethers in plastic from WEEE/ EEE in Nigeria as a basis for policy advice. Environ Sci Pollut Res Int 22:14502-14514

27. Statista (2018) Per capita consumption of plastic materials worldwide in 2015 by region. https://www.statista.com/statistics/270312/consu mption-of-plastic-materials-per-capita-since-1980/. Accessed $18 \mathrm{Mar}$ 2019

28. World Population Review (2019) Africa Population 2019. http://world populationreview.com/continents/africa-population/. Accessed 15 Mar 2019

29. EUROMAP (2016) Plastics resin production and consumption in 63 countries worldwide. http://www.pagder.org/images/files/eurom appreview.pdf. Accessed 12 Aug 2019

30. AnswersAfrica (2018) List of countries in Africa by population. https:// answersafrica.com/african-countries.html. Accessed 15 Mar 2019

31. Carmichael A (2015) Man-made fibers continue to grow. Textile World Innovation Forum. https://www.textileworld.com/textile-world/fiber -world/2015/02/man-made-fibers-continue-to-grow/

32. Henry B, Laitala K, Klepp IG (2019) Microfibres from apparel and home textiles: prospects for including microplastics in environmental sustainability assessment. Sci Total Environ 652:483-494. https://doi. org/10.1016/j.scitotenv.2018.10.166

33. Sun J, Dai X, Wang Q, van Loosdrecht MCM, Ni B-J (2019) Microplastics in wastewater treatment plants: detection, occurrence and removal. Water Res 152:21-37. https://doi.org/10.1016/j.watres.2018.12.050

34. IFEU (2018) Understanding system challenges in international trade statistics for material flow analysis. Ifeu Working Paper 2/2018. Institute for Energy and Environmental Research Heidelberg. https://www.ifeu. de/wp-content/uploads/ifeu_Working_Paper_2.pdf

35. Sweep Net (2014) Country report on solid waste management in Algeria. https://www.retech-germany.net/fileadmin/retech/05_media thek/laenderinformationen/Algerien_RA_ANG_WEB_O_Laenderpro file_sweep_net.pdf

36. Ibrahim M, Mohamed NAM (2016) Towards sustainable management of solid waste in Egypt. Procedia Environ Sci 34:336-347

37. Babayemi JO, Dauda KT (2009) Evaluation of solid waste generation, categories and disposal options in developing countries: a case study of Nigeria. J Appl Sci Environ Manage 13(3):83-88

38. Kawai K, Tasaki T (2016) Revisiting estimates of municipal solid waste generation per capita and their reliability. J Mater Cycles Waste Manage 18(1):1-13. https://doi.org/10.1007/s10163-015-0355-1

39. ESI Africa (2018) S. Africa: $1.144 \mathrm{~m}$ tonnes of recyclable plastic dumped in landfills. https://www.esi-africa.com/top-stories/s-africa-1-144m-tonne s-of-recyclable-plastic-dumped-in-landfills/. Accessed 5 June 2019

40. Brooks AL, Wang S, Jambeck JR (2018) The Chinese import ban and its impact on global plastic waste trade. Vol 4, no. 6, pp eaat0131. https:// doi.org/10.1126/sciadv.aat0131. https://advances.sciencemag.org/conte nt/4/6/eaat0131.full

41. Katz C (2019) Piling up: how china's ban on importing waste has stalled global recycling. Yale Environment 360, https://e360.yale.edu/features/ piling-up-how-chinas-ban-on-importing-waste-has-stalled-global-recyc ling

42. Collings J (2002) Mind over matter: the sasol story: a half-century of technological innovation. ISBN: 0620289333; 9780620289337. Johannesburg, South Africa

43. Selby D (2017) Plastic Production Is Set to Increase by $40 \%$ Over the Next Decade, Experts Say. December 26, 2017. https://www.globalcitizen.org/ en/content/plastic-production-increase-pollution-ocean-waste/

44. Mongsawad (2010) The Philosophy of the sufficiency economy: a contribution to the theory of development. Asia-Pacific J Rural Develop 17(1):123-143

45. Alexander S (2012) The optimal material threshold: toward an economics of sufficiency. Real-World Economics Review, issue no. 61
46. ARC+ (2008) Plastic bags-policies and practices to reduce consumption assessing the application of policies to lightweight single use polyethylene plastic bags. 2008 Update. http://www.acrplus.org/en/2-conte nt/296-report-plastic-bags-policies-and-practices-to-reduce-consumptio n

47. European Union (2019) DIRECTIVE OF THE EUROPEAN PARLIAMENT AND OF THE COUNCIL on the reduction of the impact of certain plastic products on the environment. Brussels, 5th June 2019. Official Journal of the European Union (L 155/1) https://eur-lex.europa.eu/legal-content/ EN/TXT/PDF/?uri=CELEX:32019L0904\&from=EN

48. Godfrey L (2019) Waste plastic, the challenge facing developing countries_ban it, change it, collect it? Recycling. 4:3. https://doi.org/10.3390/ recycling 4010003

49. UN Environment (2017) Ethiopia's waste-to-energy plant is a first in Africa. UN Environment news and stories, 24. November 2017, https:// www.unenvironment.org/news-and-stories/story/ethiopias-waste-energ $y$-plant-first-africa

50. Ministry of Infrastructure (2015) National Housing Policy. Final Draft 17/03/2015. http://www.rha.gov.rw/fileadmin/user_upload/Documents/ Policies/National_Housing_Policy.pdf

51. The New Times (2018) House passes bill to ban single-use plastics. Hudson Kuteesa \& Viviane Irabizi. 2019.https://www.newtimes.co.rw/news/ house-passes-bill-ban-single-use-plastics

52. International Monetary Fund (2018) Report for selected countries and subjects. Rwanda, International Monetary Fund

53. Babayemi JO, Osibanjo O, Sindiku O, Weber R (2018) Inventory and substance flow analysis of polybrominated diphenyl ethers in the Nigerian transport sector-basis for end-of-life vehicles policy and management. Environ Sci Pollut Res 25(32):31805-31818

54. Areeprasert C, Asingsamanunt J, Srisawat S, Kaharn J, Inseemeesak B, Phasee P, Khaobang C, Siwakosit W, Chiemchaisri C (2017) Municipal plastic waste composition study at transfer station of bangkok and possibility of its energy recovery by pyrolysis. Energy Procedia 107:222-226. https:// doi.org/10.1016/j.egypro.2016.12.132

55. Quartey ET, Tosefa H, Danquah KAB, Obrsalova I (2015) Theoretical framework for plastic waste management in ghana through extended producer responsibility: case of sachet water waste. Int J Environ Res Public Health 12:9907-9919. https://doi.org/10.3390/ijerph120809907

56. Nyarko AD, Adu KJ (2016) Impact of sachet water and plastic bottle waste on agricultural land in the Ada East District of Ghana. Asian Res J Agric 1(3):1-10

57. Association of African Entrepreneurs (2017) Remove, reduce, and recycle - the waste nylon sachet water in Nigeria. http://www.aaeafrica. org/home/remove-reduce-recycle-waste-nylon-sachet-water-nigeria/. Accessed 25 Mar 2019

58. Cogut A (2016) Open burning of waste: a global health disaster. R20 Regions of Climate Action, October 2016

59. Morales SRGE, Toro AR, Morales L, Leiva GMA (2018) Landfill fire and airborne aerosols in a large city: lessons learned and future needs. Air Qual Atmos Health 11:111-121

60. Oloruntoba K, Sindiku O, Osibanjo O, Balan S, Weber R (2019) Polybrominated diphenyl ethers (PBDEs) in chicken eggs and cow milk around municipal dumpsites in Abuja, Nigeria. Ecotoxicol Environ Saf. 179:282-289

61. Sindiku O, Babayemi J, Osibanjo O, Schlummer M, Schluep M, Watson A, Weber R (2015) Polybrominated diphenyl ethers listed as Stockholm Convention POPs, other brominated flame retardants and heavy metals in E-waste polymers in Nigeria. Environ Sci Pollut Res Int 22:14489-14501

62. Dussud C, Pujo-Pay M, Conan P, Crispi O, Elineau A, Petit S, Gorsky G, Pedrotti ML, Fabre P, George M, Ghiglione JF (2017) Plastic litter: a new habitat for marine microbial communities. In: Baztan J, Jorgensen B, Pahl S, Thompson RC, Vanderlinden JP (eds) Fate and impact of microplastics in marine ecosystems. Elsevier, Amsterdam. https://doi.org/10.1016/ B978-0-12-812271-6.00076-4

63. Gallo F, Fossi C, Weber R, Santillo D, Sousa J, Ingram I, Nadal A, Romano D (2018) Marine litter plastics and microplastics and their toxic chemicals components: the need for urgent preventive measures. Environ Sci Eur 30:13. https://doi.org/10.1186/s12302-018-0139-z

64. Babayemi JO, Ogundiran MB, Osibanjo O (2017) Current levels and management of solid wastes in Nigeria. Environ Qual Manage 26(3):29-53 
65. Weber R, Herold C, Hollert H, Kamphues J, Blepp M, Ballschmiter K (2018) Reviewing the relevance of dioxin and PCB sources for food from animal origin and the need for their inventory, control and management. Environ Sci Eur. 30:42. https://rdcu.be/bax79

66. Weber R, Bell L, Watson A, Petrlik J, Paun MC, Vijgen J (2019) Assessment of POPs contaminated sites and the need for stringent soil standards for food safety for the protection of human health. Environ Pollut 249:703-715

67. UN Environment/MAP, SCP/RAC (2017) 25 innovative solutions to combat plastic marine litter: an unique tool for businesses, entrepreneurs and civil society organizations in the Med Region to take action. 12th December 2017. http://www.cprac.org/ca/arxiu-de-noticies/generiques/25-innov ative-solutions-to-combat-plastic-marine-litter-a-unique-tool-f

68. Hopewell J, Dvorak R, Kosinor E (2009) Plastics recycling: challenges and opportunities, Philos. Trans R Soc Lond B Biol Sci 364:2115-2126

69. Plastics South Africa (2018) Annual Review 2017/18. https://www.plast icsinfo.co.za/annual-reports/. Accessed 13 June 2019

70. Eunomia (2018) Plastic packaging shedding light on the UK Data

71. Macharia K (2017) Kenyan firm first in Africa to convert plastic waste to synthetic fuel oil. Capital Business. https://www.capitalfm.co.ke/busin ess/2017/02/kenyan-firm-first-in-africa-to-convert-plastic-waste-to-synth etic-fuel-oil/

72. Benson W.C (2019) Companies Launch African Plastics Recycling Alliance. SDG Knowledge Hub. Institute for Sustainable Development (IISD), 1 April 2019. https://sdg.iisd.org/news/companies-launch-african-plastics-recyc ling-alliance/
73. Plastics Insight (2017) World's top 10 importing countries for polyethylene polymer in 2015. https://www.plasticsinsight.com/worlds-top-10-importing-countries-olyethylene-polymer-2015/. Accessed 8 Feb 2018

74. Trucost (2016) Plastics and sustainability: a valuation of environmental benefits, costs and opportunities for continuous improvement. https:// plastics.americanchemistry.com/Plastics-and-Sustainability.pdf. Accessed 22 Mar 2019

75. GIZ (2018) Circular Economy Briefing Series. https://www.giz.de/de/ downloads/giz2018_Thailand-Country-Profile_web.pdf https://www.giz. de/de/downloads/giz2018_ASEAN-Packaging-Waste_web.pdf

76. OECD (2018) Improving plastics management: trends, policy responses, and the role of international co-operation and trade. OECD environment policy paper no. 12

77. CM Consulting and Reloop (2018) Deposit systems for one-way beverage containers: Global overview. https://reloopplatform.eu/wp-content/ uploads/2018/05/BOOK-Deposit-Global-27-APR2018.pdf

78. Aguado J, Serrano DP, Miguel GS (2007) European trends in the feedstock recycling of plastic wastes. Global NEST J 9(1):12-19

\section{Publisher's Note}

Springer Nature remains neutral with regard to jurisdictional claims in published maps and institutional affiliations.

\section{Submit your manuscript to a SpringerOpen ${ }^{\circ}$ journal and benefit from:}

- Convenient online submission

- Rigorous peer review

- Open access: articles freely available online

- High visibility within the field

- Retaining the copyright to your article

Submit your next manuscript at $>$ springeropen.com 